\title{
North Atlantic and North Sea Climate Change: curl up, shut down, NAO and Ocean Colour
}

\author{
Robin Pingree \\ The Laboratory, Citadel Hill, Plymouth, PL1 2PB, UK. E-mail rdpi@mba.ac.uk \\ Plymouth Marine Laboratory, Prospect Place, The Hoe, Plymouth, PL1 3DH, UK
}

\begin{abstract}
The strength of the North Atlantic Current (NAC) (based on sea-surface elevation slopes derived from altimeter data) is correlated with westerly winds (based on North Atlantic Oscillation [NAO] Index data over a nine year period [1992-2002] with 108 monthly values). The data time window includes the major change in climate forcing over the last 100 years (1995 to 1996). It is shown that the NAO Index can be used for early warning of system failure for the NAC. The correlation response or early warning time scale for western Europe and south England is six months. The decay scale for the NAC and Subtropical Gyre circulation is estimated as three years. Longer period altimeter elevation/circulation changes are discussed. The sea-surface temperature (SST) response of the North Sea to negative and positive NAO conditions is examined. The overall temperature response for the central North Sea to NAO index forcing, reflecting wind induced inflow, shelf circulation and local climate forcing, is $\sim 5$ months. In years with strong North Atlantic winter wind induced inflow, under marked NAO positive conditions, mean temperatures $\left(\sim 10.5^{\circ} \mathrm{C}\right)$ are about $1^{\circ} \mathrm{C}$ warmer than under negative conditions. In 1996 under extreme negative winter NAO conditions, the North Sea circulation stopped, conditions near the Dogger Bank became more continentally influenced and the winter (March) temperature fell to $3.1^{\circ} \mathrm{C}$ whereas in 1995 under NAO positive winter conditions the minimum temperature was $6.4^{\circ} \mathrm{C}$ (February). Seasonal advance of North Atlantic and North Sea temperature is derived in relation to temperature change. Temperature change and monthly NAO Index are discussed with respect to phytoplankton blooms, chlorophyll- $a$ measurements, ocean colour data and the anomalous north-eastern Atlantic 2002 spring/summer bloom SeaWiFS chlorophyll concentrations.
\end{abstract}

\section{INTRODUCTION}

There has been much speculation about the Gulf Stream shutting down and the consequences for climate change in Europe both in the media (e.g. The Day after Tomorrow) and in popular scientific news or publicity articles (e.g. rapidmoc (2004)). For advice to governments, some quantification is required. Talk is often so loose that it is not clear whether the shut down refers to the Gulf Stream or the Global Conveyor Belt (or Thermohaline Circulation paths of cold and warm water). Indeed, it would be useful to have a more precise definition in time and space of the Global Conveyor Belt in the North Atlantic (shown in UK WOCE: Understanding Ocean Circulation, for example) so appraisals can be made as to the relative roles of the Florida Current, Gulf Stream, the North Atlantic Current (or the North Atlantic Drift) and the Global Conveyor Belt in transporting heat and ameliorating the climate of West Europe and subpolar regions. The Hadley Centre (Met Office) model forecasts that the Gulf Stream will slow down by $20 \%$ by 2050 , but that the cooling effect is more than offset by Global Warming. A final balance must also consider Global Dimming and cooling (Stanhill \& Cohen, 2001). It is generally considered that we are in a climate phase of accelerated warming coupled with increased high frequency temperature variance.

In this paper, it is shown that a quantitative evaluation of timescale and cause of shut down of the North Atlantic
Current (NAC) can be made with data that are in the public domain. This allows appraisal of scientific debate with respect to North Atlantic Ocean rapid climate change. Conditions in the North Sea are then examined. Some anomalous seasonal cycles of SeaWiFS chlorophyll- $a$ concentration are identified.

\section{MATERIALS AND METHODS}

The remote sensing data used in this paper are from the ERS 1/2 and Topex Poseidon satellites with altimeter data covering a $\sim 9$ y period from October 1992 to October 2001 and processed according to Le Traon et al. (1998). Altimeter data analysis methods for determining seasurface slope and ocean currents are now well established (Cromwell \& Smeed, 1998; Pingree et al., 2002). Estimates of mean water transports (usually measured in Sverdrups $(\mathrm{Sv})$ ) from conductivity-temperature-depth probe (CTD) stations can be unreliable if the station spacing does not resolve mesoscale eddies. However, corrections for transport can be made with extra resolution from expendable bathythermographs (XBTs) across a station position or using altimetry data to resolve eddy structure and so calculate an end transport correction. The altimeter time series data at a position were derived with $5^{\circ} \times 5^{\circ}$ (latitude by longitude) spatial averaging to remove mesoscale time varying structures recently 
characterized by latitude $\left(20^{\circ} \mathrm{N}\right.$ to $\left.50^{\circ} \mathrm{N}\right)$ for the North Atlantic Ocean (Pingree, 2002). The NAO winter and monthly index data were taken from www.cgd.ucar.edu/ cas/jhurrell/nao.stat.winter.html (e.g. Hurrell, 1995). The winter (December through March) index of the NAO is based on the difference of normalized sea level pressure (SLP) between Lisbon, Portugal and Stykkisholmur Reykjavik. For the correlation results between the ocean circulation or remote sensing data (derived from altimeter differences) and westerly wind (NAO Index or meteorological data derived from atmospheric pressure differences), the seasonal station NAO monthly indices (with annual running mean) based on the difference of normalized sea level pressure between Ponta Delgada, Azores and Stykkisholmur Reykjavik are used. This is because Ponta Delgada $\left(\sim 38^{\circ} \mathrm{N} 26^{\circ} \mathrm{W}\right)$ is more centrally positioned in the North Atlantic Ocean. Dynamic height differences and transport were derived from cruise data (Pingree,

Table 1. Annual component (cm, phase ${ }^{\circ}$ ) of sla (sea level anomaly) at positions at the end of the $2000 \mathrm{~km}$ North Atlantic Current $(\mathcal{N} A C)$ and $26^{\circ} \mathcal{N}$ (Subtropical Gyre $(S T G)$ ) sections and sea-surface temperature $\left({ }^{\circ}\right.$ C, phase $\left.{ }^{\circ}\right)$ for the North Sea. The variance in the annual signal is removed in the analysis.

\begin{tabular}{|c|c|c|c|c|c|c|}
\hline Position & Date & Mean & $\begin{array}{c}\text { Annual } \\
\text { component }\end{array}$ & $\begin{array}{l}\text { Semi-annual } \\
\text { component }\end{array}$ & Region & $\begin{array}{l}\% \text { of total variance in } \\
\text { the annual component }\end{array}$ \\
\hline $\begin{array}{l}55.5^{\circ} \mathrm{N} \\
35^{\circ} \mathrm{W} \\
\left(5^{\circ} \text { latitude } \times 5^{\circ} \text { longitude }\right) \\
\text { Average }\end{array}$ & $\begin{array}{c}\text { sla } \\
\text { October } 92 \text { to } \\
\text { September } 2001 \\
329 \text { values } \\
\text { Monthly }\end{array}$ & 0 & $\begin{array}{c}4.4 \mathrm{~cm} \\
\text { Amplitude } \\
257^{\circ} \\
\text { Phase }^{\dagger}\end{array}$ & & NAC & $58 \%$ \\
\hline $\begin{array}{l}37.5^{\circ} \mathrm{N} \\
35^{\circ} \mathrm{W}\end{array}$ & & 0 & $\begin{array}{c}5.4 \mathrm{~cm} \\
272^{\circ}\end{array}$ & & NAG & $61 \%$ \\
\hline $\begin{array}{l}26^{\circ} \mathrm{N} \\
50^{\circ} \mathrm{W}\end{array}$ & & 0 & $\begin{array}{c}5.3 \mathrm{~cm} \\
264^{\circ}\end{array}$ & & $\begin{array}{l}26^{\circ} \mathrm{N} \\
\text { STG }\end{array}$ & $77 \%$ \\
\hline $\begin{array}{l}26^{\circ} \mathrm{N} \\
30^{\circ} \mathrm{W}\end{array}$ & & 0 & $\begin{array}{c}5.3 \mathrm{~cm} \\
270^{\circ}\end{array}$ & & $\begin{array}{l}26^{\circ} \mathrm{N} \\
\mathrm{STG}\end{array}$ & $79 \%$ \\
\hline $\begin{array}{l}55^{\circ} \mathrm{N} \\
3^{\circ} \mathrm{E} \\
\left(2^{\circ} \text { latitude } \times 2^{\circ} \text { longitude }\right) \\
\text { Average }\end{array}$ & $\begin{array}{c}\text { SST } \\
\text { October } 92 \text { to } \\
\text { September } 2001 \\
108 \text { values }\end{array}$ & $10.33^{\circ} \mathrm{C}$ & $\begin{array}{l}5.20^{\circ} \mathrm{C} \\
230^{\circ}\end{array}$ & $\begin{array}{c}0.73^{\circ} \mathrm{C} \\
68^{\circ}\end{array}$ & $\begin{array}{l}\text { North } \\
\text { Sea }\end{array}$ & $93 \%$ \\
\hline \multirow{10}{*}{$\begin{array}{l}55^{\circ} \mathrm{N} \\
3^{\circ} \mathrm{E}\end{array}$} & & & & & $\begin{array}{l}\text { North } \\
\text { Sea }\end{array}$ & \\
\hline & $\begin{array}{l}1946-1955 \\
120 \text { values }\end{array}$ & $10.11^{\circ} \mathrm{C}$ & $\begin{array}{c}5.24^{\circ} \mathrm{C} \\
235^{\circ}\end{array}$ & $\begin{array}{c}0.63^{\circ} \mathrm{C} \\
49^{\circ}\end{array}$ & Decade & $94 \%$ \\
\hline & 1956-1965 & $10.01^{\circ} \mathrm{C}$ & $\begin{array}{c}5.05^{\circ} \mathrm{C} \\
236^{\circ}\end{array}$ & $\begin{array}{c}0.49^{\circ} \mathrm{C} \\
32^{\circ}\end{array}$ & Decade & $94 \%$ \\
\hline & $1966-1975$ & $10.18^{\circ} \mathrm{C}$ & $\begin{array}{c}5.24^{\circ} \mathrm{C} \\
233^{\circ}\end{array}$ & $\begin{array}{c}0.70^{\circ} \mathrm{C} \\
54^{\circ}\end{array}$ & Decade & $95 \%$ \\
\hline & 1976-1985 & $9.98^{\circ} \mathrm{C}$ & $\begin{array}{c}5.37^{\circ} \mathrm{C} \\
234^{\circ}\end{array}$ & $\begin{array}{c}0.58^{\circ} \mathrm{C} \\
47^{\circ}\end{array}$ & Decade & $96 \%$ \\
\hline & 1986-1995 & $10.29^{\circ} \mathrm{C}$ & $\begin{array}{c}4.92^{\circ} \mathrm{C} \\
230^{\circ}\end{array}$ & $\begin{array}{c}0.69^{\circ} \mathrm{C} \\
53^{\circ}\end{array}$ & Decade & $93 \%$ \\
\hline & $\begin{array}{l}1946-1995 \\
600 \text { values }\end{array}$ & $10.11^{\circ} \mathrm{C}$ & $\begin{array}{l}5.16^{\circ} \mathrm{C} \\
233.5^{\circ}\end{array}$ & $\begin{array}{c}0.61^{\circ} \mathrm{C} \\
48^{\circ}\end{array}$ & $\begin{array}{c}50 \text { year } \\
\text { Period }\end{array}$ & $94 \%$ \\
\hline & $\begin{array}{l}1989-1995 \\
84 \text { values }\end{array}$ & $10.54^{\circ} \mathrm{C}$ & $\begin{array}{c}4.85^{\circ} \mathrm{C} \\
228^{\circ}\end{array}$ & $\begin{array}{l}0.76^{\circ} \mathrm{C} \\
60^{\circ}\end{array}$ & $\begin{array}{l}\text { Positive } \\
\mathrm{NAO}+3\end{array}$ & $94 \%$ \\
\hline & $\begin{array}{c}1936,1963 \\
1969,1996 \\
48 \text { values }\end{array}$ & $9.54^{\circ} \mathrm{C}$ & $\begin{array}{c}5.84^{\circ} \mathrm{C} \\
235^{\circ}\end{array}$ & $\begin{array}{c}0.83^{\circ} \mathrm{C} \\
48^{\circ}\end{array}$ & $\begin{array}{l}\text { Negative } \\
\mathrm{NAO}-4\end{array}$ & $95 \%$ \\
\hline & $\begin{array}{c}1996 \\
12 \text { values }\end{array}$ & $9.09^{\circ} \mathrm{C}$ & $\begin{array}{c}5.95^{\circ} \mathrm{C} \\
239^{\circ}\end{array}$ & $\begin{array}{c}0.78^{\circ} \mathrm{C} \\
55^{\circ}\end{array}$ & $\begin{array}{l}\text { Negative } \\
\mathrm{NAO}-4\end{array}$ & $98 \%$ \\
\hline
\end{tabular}

\footnotetext{
$\dagger$, Phase $0^{\circ}$ and $360^{\circ}$ corresponds to 1 January for the annual component. For example, a North Sea phase of 228 ${ }^{\circ}(1989-1995$, with seven year maximum average temperature of $10.54^{\circ} \mathrm{C}$ during the $\sim 56$ year period) is yearday 231 or 19 August (when not a leap year). For the semi-annual component, there are two peaks in the year and the phase of $60^{\circ}$ results in a maximum at the end of January/ beginning of February and end of July/beginning of August for the second largest component in the temperature spectrum $(\sim 1 \%$ of the total temperature variance).
} 


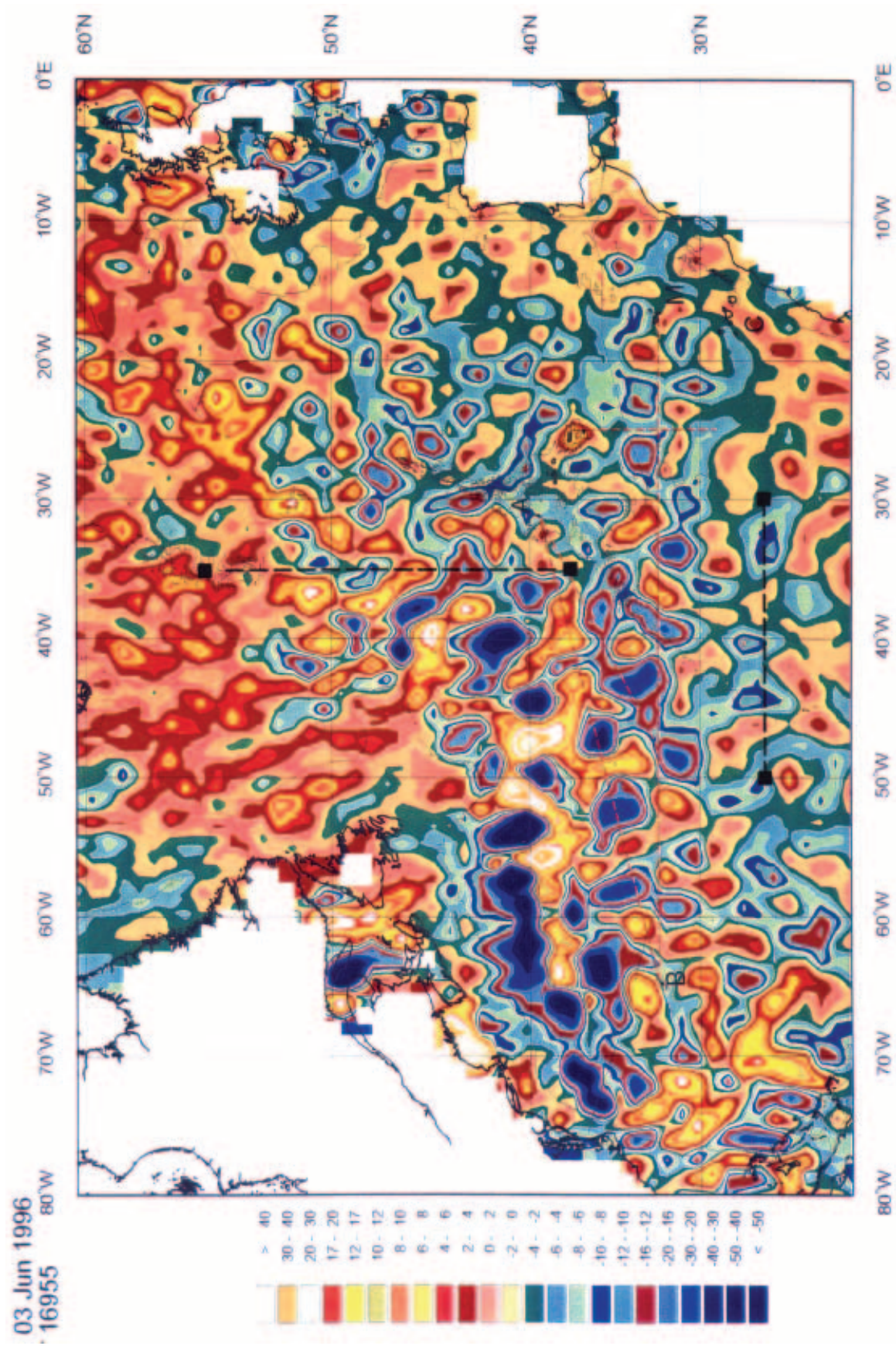

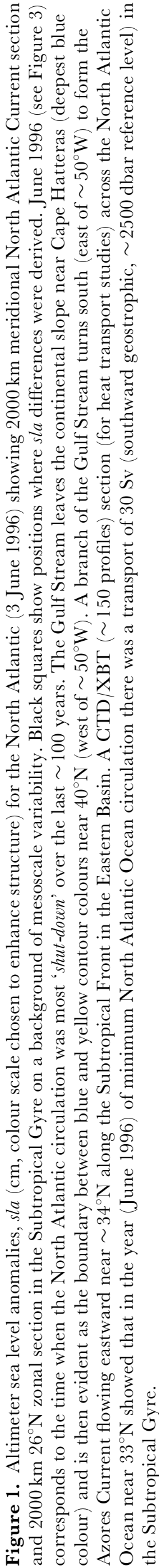




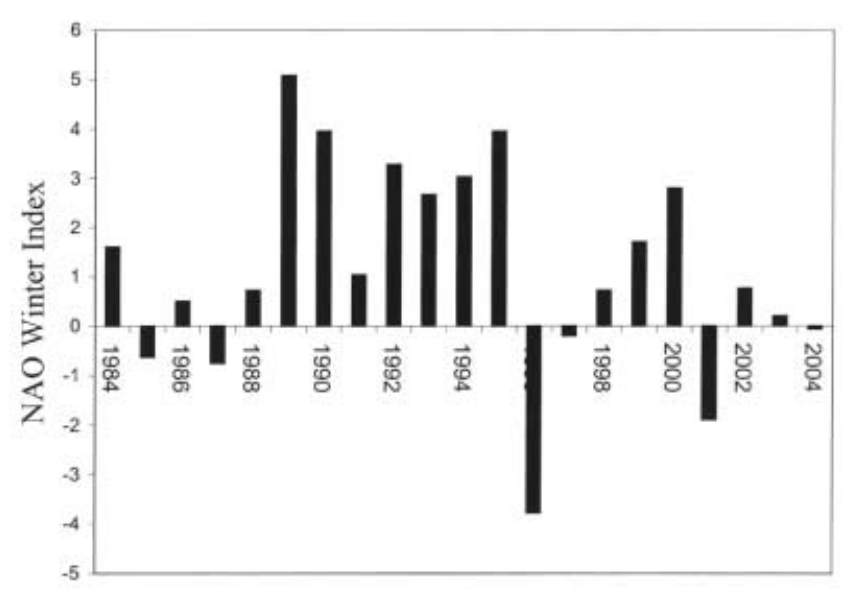

Figure 2. Twenty year time series of North Atlantic Oscillation winter (December-March) Index from 1984 to 2004. The major changes related to North Atlantic and North Sea climate and circulation occur in 1988 to 1989,1995 to 1996 and 2000 to 2001.

2002), the World Ocean Atlas (WOA94) historical data base (Levitus \& Boyer, 1994) or cruise report data (e.g. Griffiths et al., 1992; PML, 1994; Pollard et al., 1996). Seasonal pressure differences between, say near $35^{\circ} \mathrm{N}$ and $60^{\circ} \mathrm{N}$ (at $\sim 30^{\circ} \mathrm{W}$ ) can be found in Admiralty Pilots or as maps (e.g. Hydrographic Department, 2002) and squaring these differences gives an approximate weighting for relative monthly wind stress strength. These data (e.g. dynamic height, CTD transports, seasonal air pressure differences) can be used to change the scales (either nondimensionalized or dimensionalized, according to preference) on the derived time-series diagrams. For the development of results to the shelf seas around the British Isles (North Sea), use is made of the Lagrangian ARGOS buoy measurements $(\sim 1500$ buoy days $)$ mainly from deployments west of Ireland near $\sim 50^{\circ} \mathrm{N} \sim 20^{\circ} \mathrm{W}$ (Pingree, 1993) in years (1989 and 1990) of expected strongest winter inflow under marked positive NAO conditions. Lagrangian or Eulerian data are preferable to transports based on CTD sections (e.g. Holliday et al., 2000) as both the Continental Slope Current and NAC in this region have a barotropic component, particularly in winter. Evidence for the absence of flow into the northern North Sea in 1996 ( February to yearday 211, 29 July) comes from measurement data from ARGOS buoy 3350 monitoring conditions of flow into the North Sea near $60^{\circ}-61^{\circ} \mathrm{N}$ (Pingree et al., 1999) under extreme negative NAO conditions. For the North Sea, sea-surface temperature data are used rather than altimeter data. This is because in coastal and shelf regions the altimeter signal is particularly noisy due to surges and wind set up and over longer time scales affected by rain, run-off and other meteorologically induced changes. The COADS data base was used for North Sea sea-surface temperature (SST) data. All the oceanographic signals are dominated by their local annual component which by definition does not change with time and is not relevant to this study. In the North Atlantic sections considered, $\sim 70 \%$ of the variance in the altimeter signal is in the annual component. For North Sea temperature, 94\% of the variance is in the annual component (Table 1). For compatible data sets, the altimeter and SST data were Fourier analysed to remove the annual component (and tidal aliasing, $\sim 62$ day periodicity). The altimeter data at ten day intervals
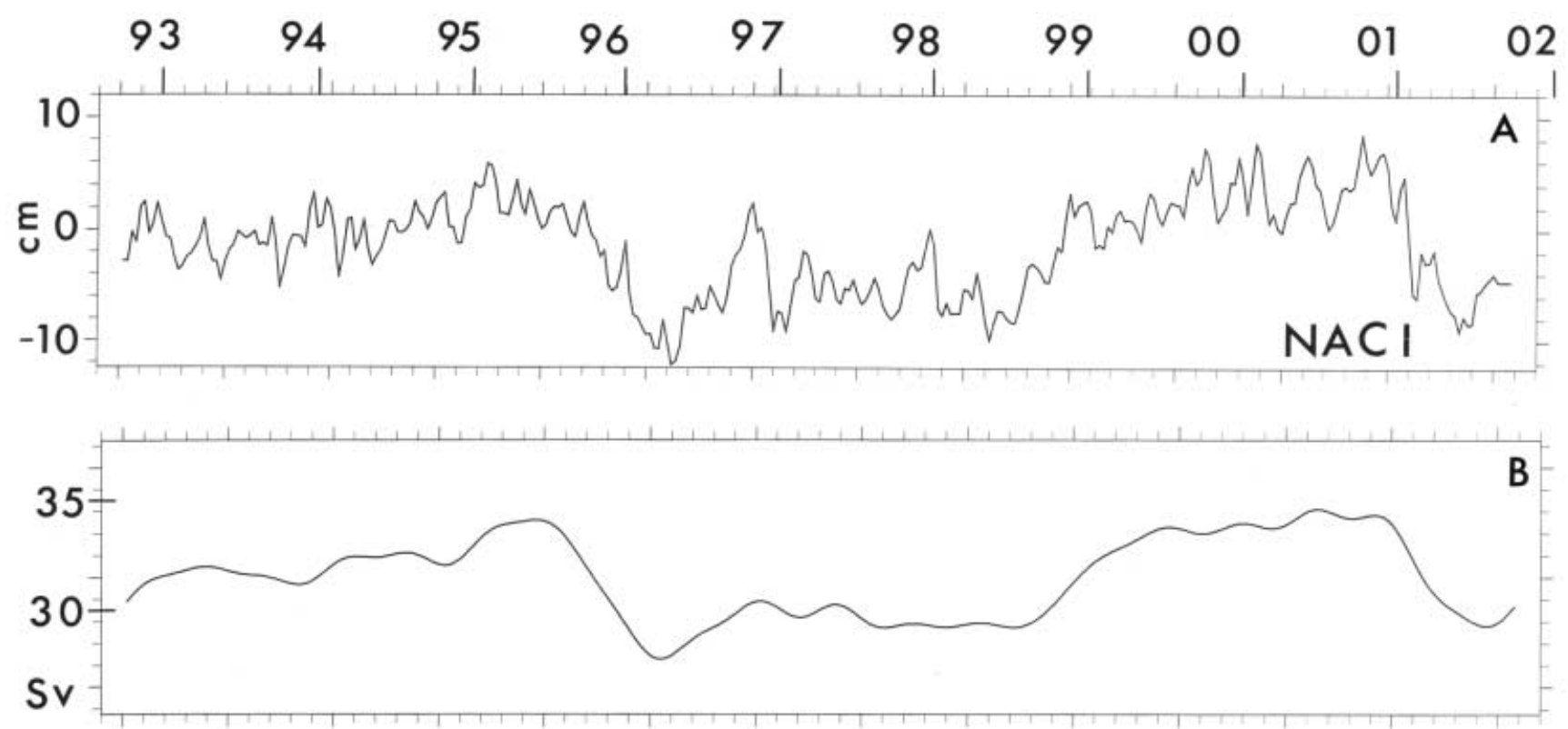

Figure 3. (A) North Atlantic Current Index (NACI, October 1992 to September 2001) with a value every ten days. The scale is in $\mathrm{cm}$ and represents the meridional difference in sea level between $55.5^{\circ} \mathrm{N}$ and $37.5^{\circ} \mathrm{N}$ at a central position $\left(35^{\circ} \mathrm{W}\right)$ in the $\mathrm{North}$ Atlantic Ocean. The value of the Index in $\mathrm{cm}$ is nondimensionalized by multiplying the scale values by $5.0 \times 10^{-9}$ to give the sea-surface slope (rad); (B) filtered North Atlantic Current (in Sv) after removing the annual component and $\sim 160$ to 20 day periods. 


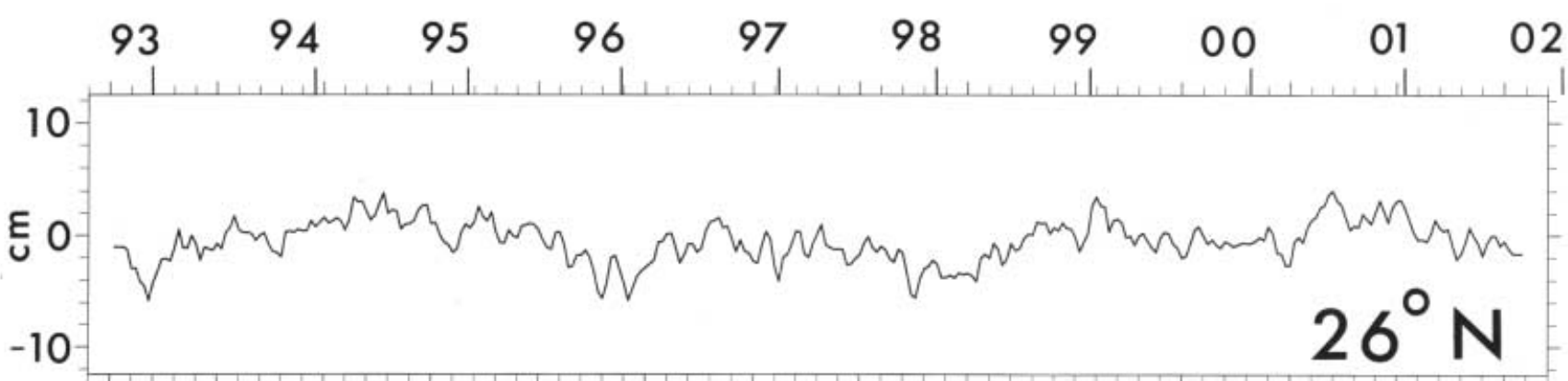

Figure 4. Zonal difference in sea-surface elevation in $\mathrm{cm}$ (or sea-surface slope $\left./ 5.0 \times 10^{-9}\right)$ for a zonal section of the Subtropical Gyre at $26^{\circ} \mathrm{N}$ (between $50^{\circ} \mathrm{W}$ and $30^{\circ} \mathrm{W}$, October 1992 to September 2001) with a value every ten days.

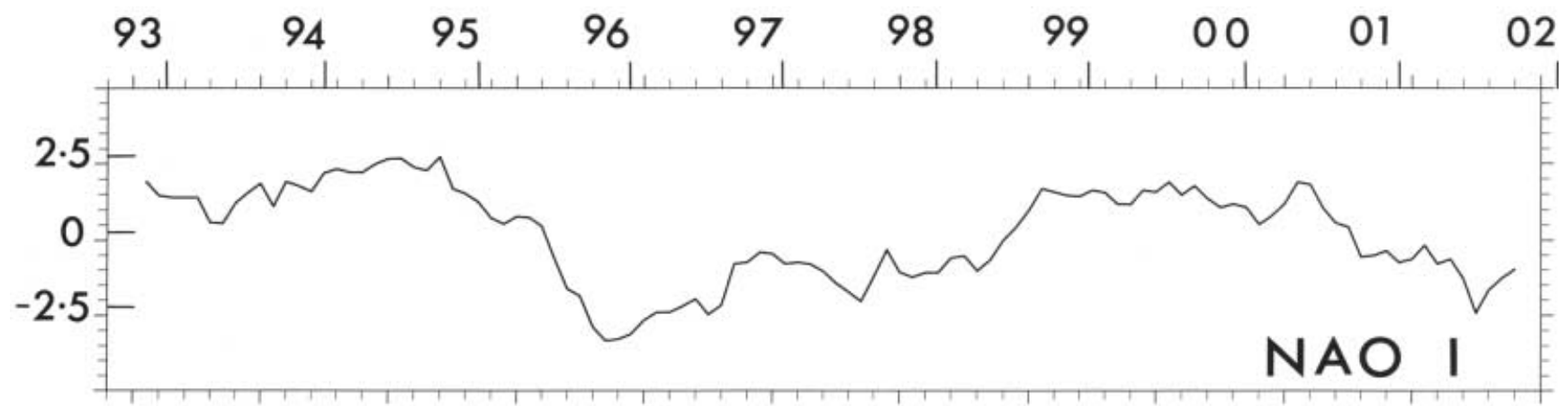

Figure 5. North Atlantic Oscillation Index (October 1992 to September 2001) at monthly values (108). Values have been rescaled for zero mean over the nine year period.

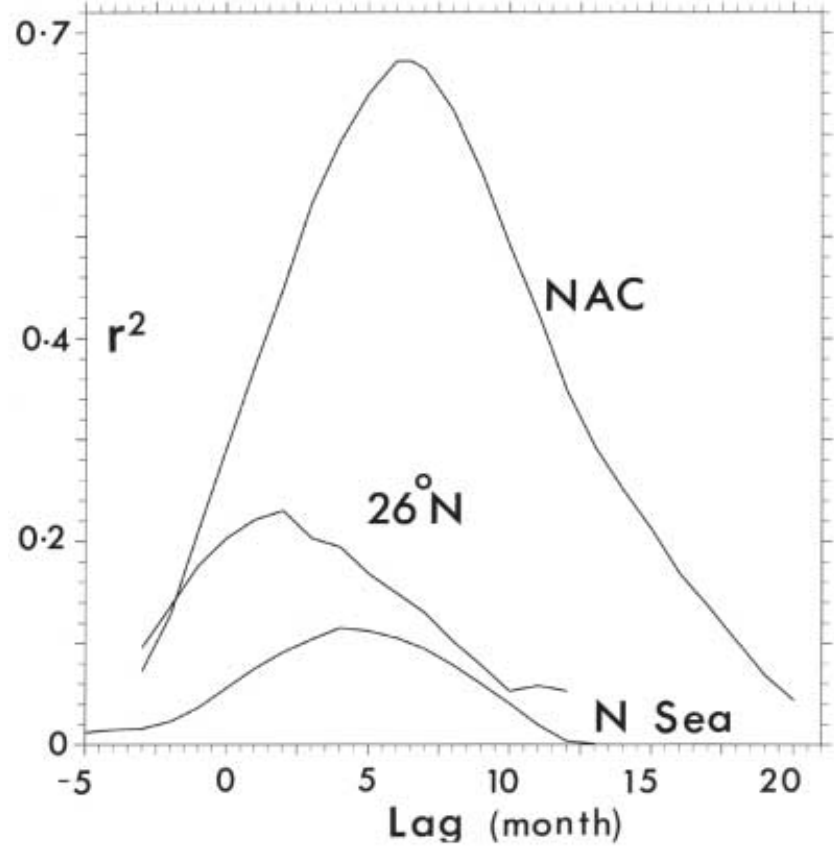

Figure 6. Correlation $\left(r^{2}\right)$ lags (months) for the North Atlantic Current $\left(2000 \mathrm{~km}\right.$ meridional section), $26^{\circ} \mathrm{N}(2000 \mathrm{~km}$ zonal section) and sea-surface temperature for the North Sea $\left(55^{\circ} \mathrm{N} 3{ }^{\circ} \mathrm{E}\right.$, Dogger Bank region) from October 1992 to September 2001 (108 values) against North Atlantic Oscillation Index.

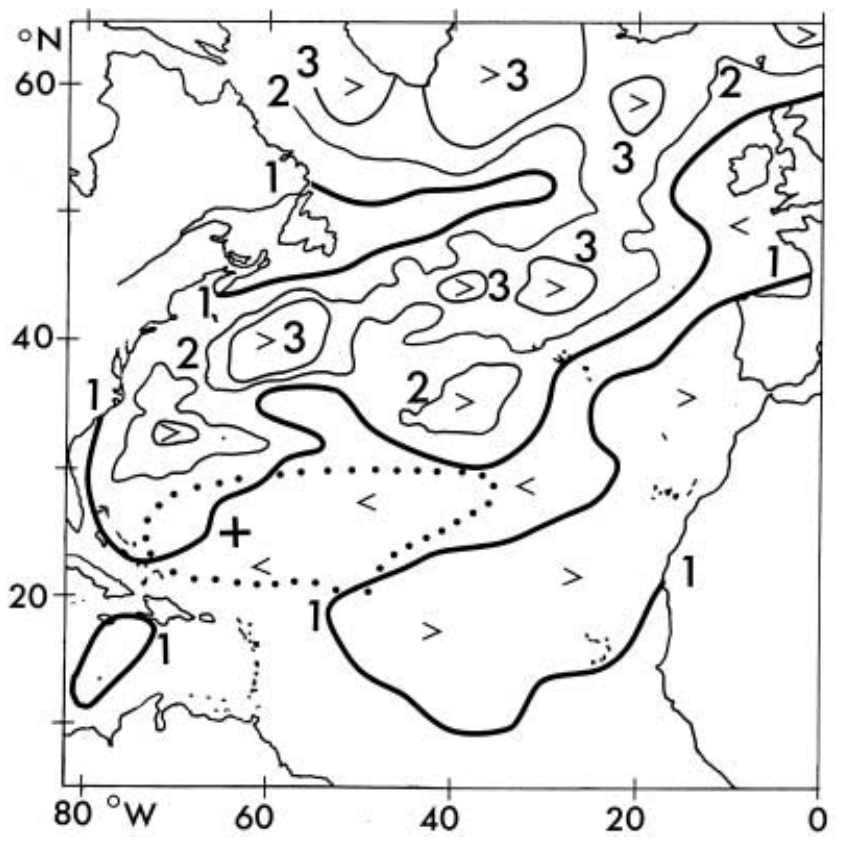

Figure 7. Amplitude $(\mathrm{cm})$ of the eight year period Fourier component of sea level change $(\times 2$ for range) in the North Atlantic Ocean derived from altimeter data. The Gulf Steam and NAC are linked by amplitude to subpolar regions. Minimum amplitude values are near $25^{\circ} \mathrm{N}$. Subtropical oligotrophic chlorophyll- $a$ low is shown by $0.075 \mathrm{mg} \mathrm{m}^{-3}$ mean SeaWiFS chlorophyll- $a$ concentration contour (dotted). The North Atlantic minimum is $0.06 \mathrm{mg} \mathrm{m}^{-3}$ at $25^{\circ} \mathrm{N} 63^{\circ} \mathrm{W}$ (five year mean, 1997-2002) and is marked by a cross. 


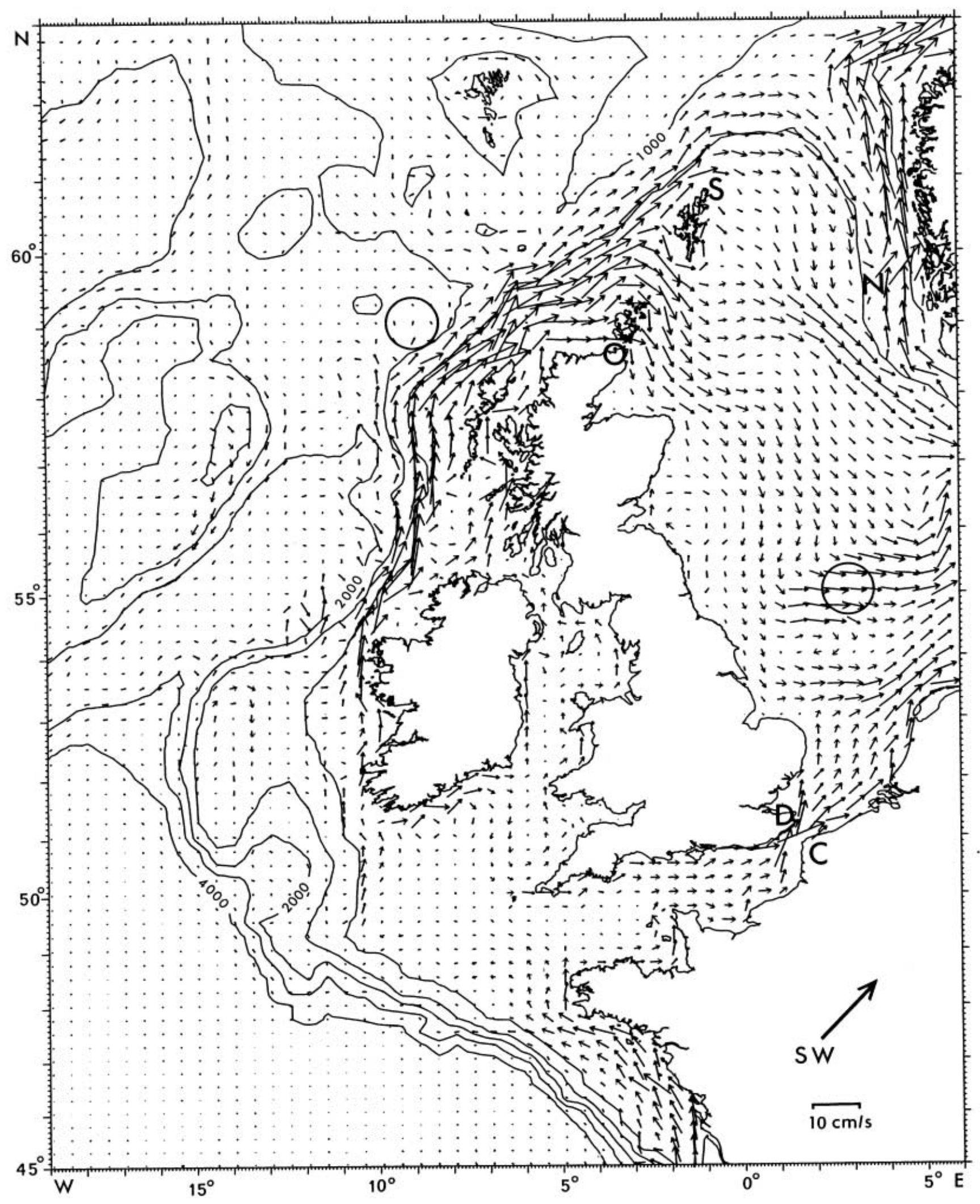

Figure 8. Wind driven currents $\left(\mathrm{cm} \mathrm{s}^{-1}\right.$ scale) around the British Isles (Pingree \& Le Cann, 1989) resulting from a mean southwest wind stress $\left(1.6\right.$ dyne $\left.\mathrm{cm}^{-2}\right)$. Shelf wind driven volume transport sections considered are DC, Dover Calais, $\left(Q_{d}\right.$ in text), SO, Shetlands Orkneys $\left(Q_{\mathrm{f}}\right.$ in text) and N, Norwegian Trench $\left(\mathbf{Q}_{\text {out }}\right.$ in text). Dogger Bank region considered is a 2 degree box centred at $55^{\circ} \mathrm{N} 3^{\circ} \mathrm{E}$ (circled). Rockall Trough and Hebrides continental shelf/slope region considered for SST and flow conditions is a 2 degree box centred at $59^{\circ} \mathrm{N} 9^{\circ} \mathrm{W}$ (circled). 


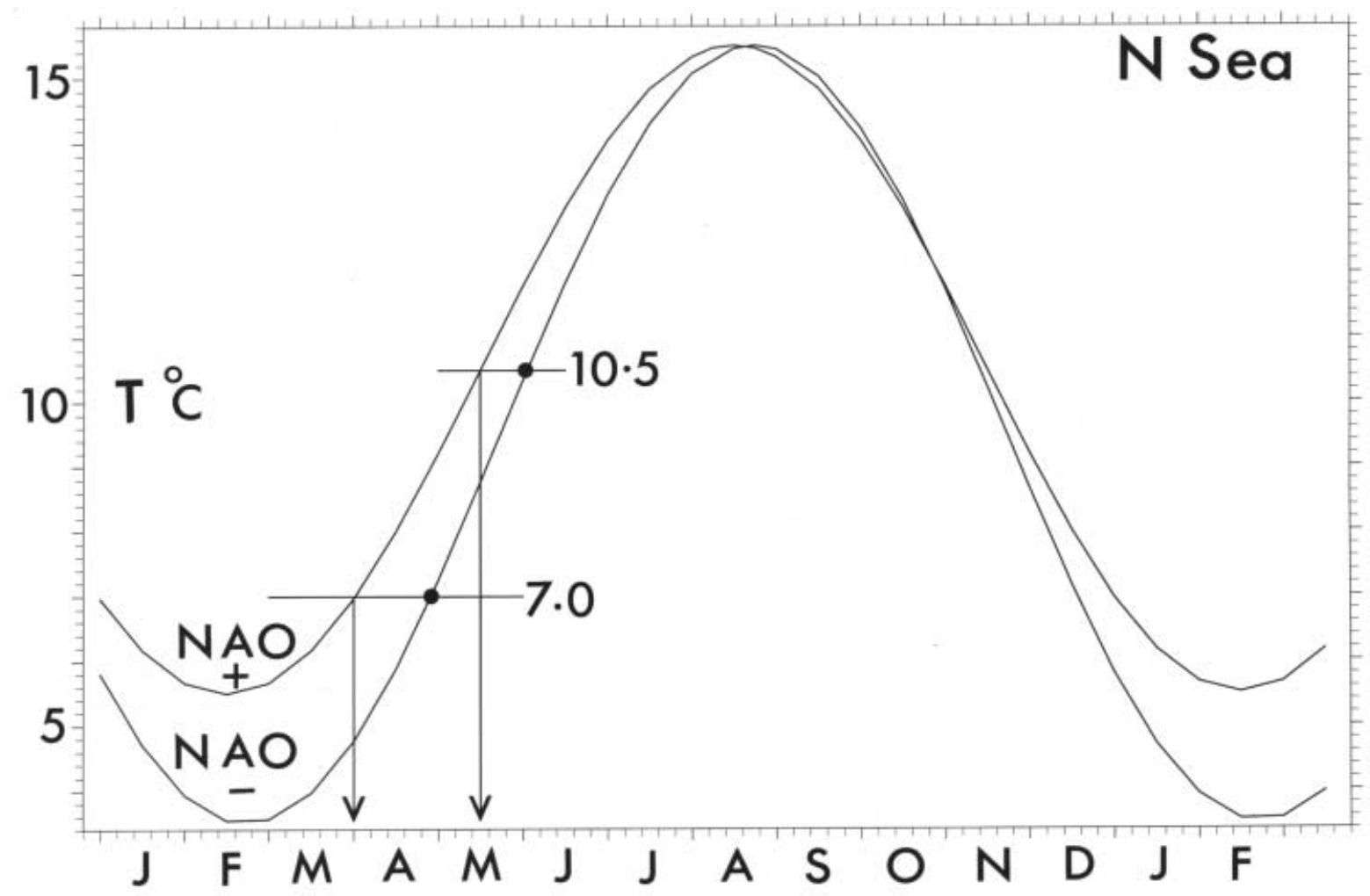

Figure 9. North Sea annual seasonal cycles (January $(\mathrm{J})$ to December $(\mathrm{D})$ ) of sea-surface temperature, $\mathrm{T}\left({ }^{\circ} \mathrm{C}\right)$, for North Atlantic Oscillation positive $(+)$ and negative $(-)$ conditions. A temperature of $7^{\circ} \mathrm{G}$ is reached a month later (bold dot) in years of NAO negative conditions with respect to positive conditions (see Appendix 1).

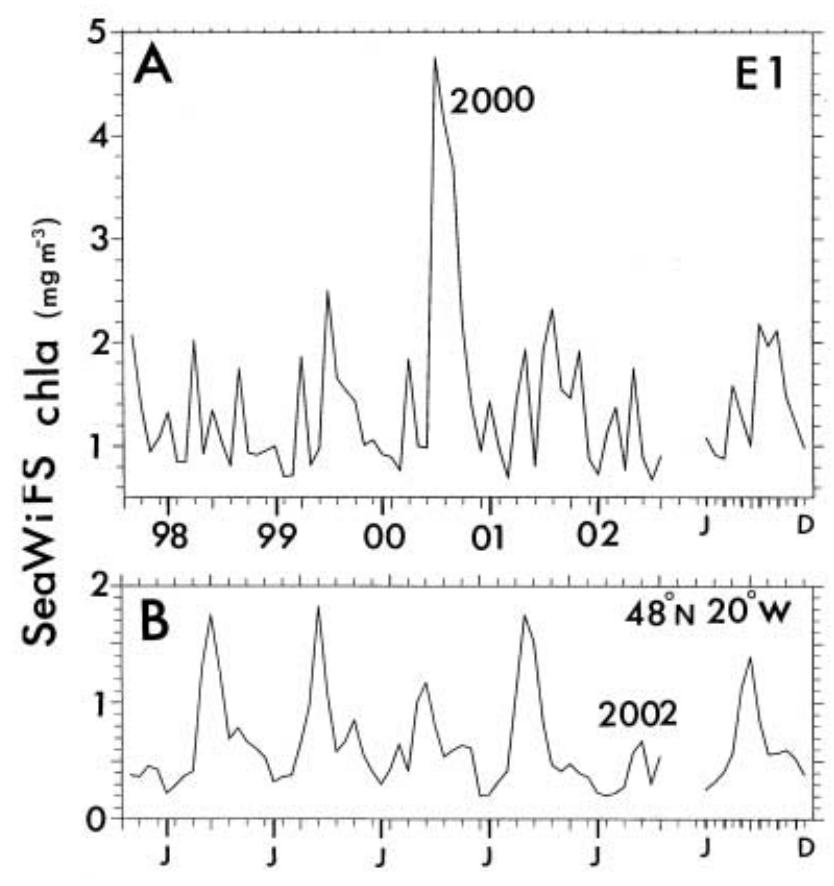

Figure 10. Anomalous seasonal cycles of SeaWiFS chlorophyll- $a\left(\mathrm{mg} \mathrm{m}^{-3}\right)$ related to North Atlantic Oscillation at (A) E1 $\left(50^{\circ} 02^{\prime} \mathrm{N} 4^{\circ} 22^{\prime} \mathrm{W}, \sim 20 \mathrm{~km}\right.$ averaging); and (B) $48^{\circ} \mathrm{N}$ $20^{\circ} \mathrm{W}$ (1 degree average) and mean annual cycles over the five year data period with mid January $(\mathrm{J})$ and mid December $(\mathrm{D})$ positions annotated. Mid January (J) for years 1998 to 2002 indicated. At E1, there is a marked bloom in July 2000. In the deep winter mixing region near $48^{\circ} \mathrm{N} 20^{\circ} \mathrm{W}$, a 2002 spring to summer bloom is absent.
Table 2. Correlation matrix for monthly sea-surface temperature for the Dogger Bank in the North Sea $\left(55^{\circ} \mathcal{N} 3^{\circ} \mathrm{E}\right)$ against monthly NAO index (1960-2003) with lags 0 to 5 months (February $\mathcal{N A O}$ bold).

\begin{tabular}{lrcrrrr}
\hline Months lagged & 0 & 1 & 2 & 3 & 4 & 5 \\
\hline January & 0.52 & 0.13 & 0.01 & -0.12 & 0.11 & 0.20 \\
February & $\mathbf{0 . 4 3}$ & 0.42 & 0.08 & 0.13 & -0.19 & 0.06 \\
March & 0.21 & $\mathbf{0 . 5 7}$ & 0.36 & 0.16 & 0.13 & -0.24 \\
April & 0.04 & 0.26 & $\mathbf{0 . 6 2}$ & 0.37 & 0.16 & 0.20 \\
May & -0.02 & 0.17 & 0.22 & $\mathbf{0 . 5 1}$ & 0.35 & 0.01 \\
June & -0.04 & -0.08 & 0.11 & 0.27 & $\mathbf{0 . 4 3}$ & 0.01 \\
July & 0.10 & -0.11 & -0.08 & 0.16 & 0.40 & $\mathbf{0 . 4 2}$ \\
August & 0.10 & 0.01 & -0.08 & -0.07 & 0.08 & 0.15 \\
September & 0.04 & 0.09 & 0.02 & -0.05 & -0.15 & -0.09 \\
October & -0.14 & -0.21 & 0.19 & -0.08 & -0.11 & -0.08 \\
November & 0.01 & -0.02 & -0.03 & -0.16 & -0.08 & -0.08 \\
December & -0.02 & 0.11 & -0.10 & 0.04 & 0.03 & -0.01 \\
\hline
\end{tabular}

were interpolated to monthly values. The end point positions (an average of 441 quarter degree values) for the $2000 \mathrm{~km}$ meridional NAG section and the $2000 \mathrm{~km}$ zonal section at $26^{\circ} \mathrm{N}$ in the Subtropical Gyre (STG) where altimeter sea level $(s l a)$ anomaly differences are derived are shown in Figure 1 (as black squares) on an sla map of North Atlantic Ocean mesoscale structure for June 1996. Examples of seasonality and change are made with respect to SST and the Atlantic Ocean in situ measurement data are taken from the Ocean Climate programme. For 
discussion of chlorophyll- $a$ levels or ocean colour, reference is made to specific relevant literature, cruise data or SeaWiFS chlorophyll- $a$ concentration data.

\section{RESULTS}

The winter NAO Index from 1984 to 2004 shows the major climate changes over the last 20 years, namely 1995/1996 and 2000/2001 (Figure 2). Indeed, the 1995/ 1996 change from high to low index is the largest change since 1881/1882. These changes are evident in the $2000 \mathrm{~km}$ meridional $\left(55.5^{\circ} \mathrm{N}\right.$ and $37.5^{\circ} \mathrm{N}$ at $\left.35^{\circ} \mathrm{W}\right)$ sea-surface slope across the NAC (Figure 3 ) and across a zonal section $\left(30^{\circ} \mathrm{W}\right.$ to $\left.50^{\circ} \mathrm{W}\right)$ of the STG at $26^{\circ} \mathrm{N}$ (Figure 4). The $2000 \mathrm{~km}$ meridional section was chosen so as to include most of the measured NAC (Richardson, 1985; Krauss, 1986). The monthly NAO Index for the same data time window (Figure 5) indicates a high correlation between the completely different types of data sets. This is quantified by deriving lagged correlation squared $\left(r^{2}\right)$ values of NAO Index against altimeter sea-surface slope for the nine year period (with 108 monthly values). The results (Figure 6) show that the NAC lags the NAO forcing by 6.5 months and that NAO changes account for $67 \%$ of the variance. The $r^{2}$ response to wind stress forcing is relatively sharp with half values in a 12 month window. By contrast, the $2000 \mathrm{~km}$ central North Atlantic Ocean section at $26^{\circ} \mathrm{N}$ in the southern part of the STG appears less sensitive to wind stress forcing with a fairly flat response that only reaches $r^{2}=0.23$. It is clearly possible to determine responses at other places in the North Atlantic. Such studies might determine what oceanic region might be optimally instrumented to monitor change and test ideas about collapse of the North Atlantic circulation (e.g. the role of 'Agulhas leakage' (Srokosz, 2003)).

For the North Sea, SST is used for the climate change property. Correlation squared lags at a central position $\left(55^{\circ} \mathrm{N} 3^{\circ} \mathrm{E}\right)$ in the North Sea show a maximum response that lags the NAO Index by 4-5 months. Interpretation of temperature change is based on measurement and numerical models of the shelf seas around the British Isles. Explanations based on SST and NAO rather than currents and NAO will be more involved and correlations (with similar data processing and averaging procedures) will generally show a weaker flatter lag response. This is because temperature at a point will depend in part (advective) on the divergence of heat flux, or for this study, the product of flow and temperature. Flow itself will result from external and local sources, and, the temperature at a point will depend on the temperature of the flow and the local climate, or local meteorological heat flux conditions, all of which may have various associations with NAO, with the product compounding overall effects.

\section{DISGUSSION AND SUMMARY}

\section{North Atlantic Ocean}

The fundamental character of the ocean controlling global change and prediction is the time varying nature of the ocean circulation. The Ocean Climate project (programme 780 ARGOS) is aimed in part at addressing West European climate change and was started in 1980. It has continued to present (2005) and includes direct measurements of flow during the major climate change events that have occurred over the last century. Some ALACE Lagrangian followers exploring ocean currents have now transmitted their data to the Marine Biological Association Laboratory continuously for ten years. Oceanography is now in a position to make bolder statements concerning flows and heat fluxes in the North Atlantic Ocean (Bower et al., 2002). In his remarkable book $A$ View of the Sea, Stommel (1987) shows that in the North Atlantic heat is lost from the ocean to the atmosphere off Ireland where the Ekman pumping is near zero (i.e. near the NAC axis). This represents the famous warming of Europe by the NAC. The work was based on the beta spiral method (Schott \& Stommel, 1978) which allows absolute values of current profiles to be determined rather than those using geostrophic methods based on CTD data. Recently a climate programme to probe the Gulf Stream for early warning of system failure (rapidmoc, 2004) has been initiated as there is a public awareness of the importance of climate change on social and economic factors and for advice to government. Wunsch (2004) has reassured Europeans that the Gulf Steam is safe and will not shut down if the wind blows and the Earth turns. However, an important component of the RAPID programme is not only to determine the flow that recirculates in the STG but also the enhancement of the surface flow (and heat flux) in the Florida Current that then continues to polar regions and which in part compensates for the deeper western boundary undercurrent. This heat flux due to meridional overturning is central to the objectives of the programme and the $26^{\circ} \mathrm{N}$ section has been chosen for study as the heat flux is thought to be a maximum at this latitude (see Srokosz, 2003) which is south of the STG central zonal axis near $\sim 30^{\circ} \mathrm{N}$. The latitude section at $24^{\circ} \mathrm{N}$ has been studied (Fuglister, 1960; Roemmich \& Wunsch, 1985; Lavin et al., 2003) and there are time-series measurements at $26^{\circ} \mathrm{N}$ over a $\sim 10$ year period (Pingree \& Garcia-Soto, 2004) to provide a useful reference for the new RAPID study at $26^{\circ} \mathrm{N}$ (e.g. Richards, 2002).

The correlation results presented here show that a $2000 \mathrm{~km}$ zonal section in the STG at $26^{\circ} \mathrm{N}$ is not as sensitive as a $2000 \mathrm{~km}$ meridional section across the NAC (at $\left.\sim 35^{\circ} \mathrm{W}\right)$ to ocean forcing by wind stress. Moreover, although not determined here, most of the net heat flux associated with the $\mathrm{NAC}$ at $\sim 35^{\circ} \mathrm{W}$ is likely to be relevant to the climate of western Europe and subpolar regions. The response of the NAG to climate forcing or time to prepare for social impact has been quantified as six months. It is not to be concluded that the central STG is less sensitive to wind stress forcing than the NAC, rather, surface currents tend to be zonal rather than meridional in both $2000 \mathrm{~km}$ regions considered (Pingree, 1996; Zhou et al., 2000) and even towards the Eastern Boundary at $26^{\circ} \mathrm{N}$ (Pingree, 1997; Weller et al., 2004). A maximum change of sea elevation of $\sim 14 \mathrm{~cm}$ occurs between 1995 and 1996. The corresponding $2000 \mathrm{~km}$ mean geostrophic surface current change across the NAC is $\sim 0.7 \mathrm{~cm} \mathrm{~s}^{-1}$. If this flow is evenly distributed through the upper $500 \mathrm{~m}$ of the water column then the volume transport change is 
7 Sv. Alternatively, estimates of transport change based on surface dynamic height differences (WOA94) and transport from CTDs give a similar value $\sim 7 \mathrm{~Sv}$ showing that the NAC is weakened by $\sim 20 \%$ within the time scale of one year (1995 to 1996) and, overall, lags the NAO Index by half a year.

Now that there are global observations of meteorological conditions (e.g. atmospheric pressure) and remote sensing observations of sea-surface properties of the World's oceans (e.g. altimeter sea-surface elevations) over many years it is possible to use global measurements to investigate a climate system. One difference between a laboratory experimental study and a global study is that it may be necessary to wait 100 years or so for a particular 'experimental' condition or 'input signal' to come up. The 1996 drop in wind stress was followed ( 6 month lag) by a drop to $80 \%$ of the initial (1995) sea-surface slope or circulation. If this is interpreted as suddenly switching off the westerly wind stress curl then an $\mathrm{e}^{-1}$ decay scale for the NAC and STG is about 27 months. A better estimate can be made by examining the local response (in 1995/1996) which shows an elevation drop of $1.7 \mathrm{~cm}$ per month (Figure 3) across the $2000 \mathrm{~km}$ section of the NAC where the mean dynamic height difference is $\sim 60$ dyn cm (WOA94 with 2000 dbar reference level, and 1/0.98 conversion factor for $\mathrm{cm}$ ). This gives a maximum decay time scale, $\mathrm{T}=3.0$ years. A second estimate in 2001/2002 (Figures $2 \& 5$ ) allows a second determination ( 31 months). The maximum value of 3.0 years can be compared with the decay of dynamic (wave/eddy) structure $\left(1200 \mathrm{~km}\right.$ scale) in the STG at $26^{\circ} \mathrm{N}$ of 1.5 years (Pingree \& Garcia-Soto, 2004).

The wider perspectives of decay scale relate to friction $(\mathrm{k} / \mathrm{H}$, Stommel's usage, where $\mathrm{k}$ is a frictional coefficient and $\mathrm{H}$ is the water depth) and diffusion $\left(\mathrm{K} \sim \mathrm{L}^{2} / \mathrm{T}\right.$, Munk's usage, where $\mathrm{L}$ is a length scale, e.g. width of the Gulf Stream) in the ocean and that both $(1200 \mathrm{~km}$ and $2000 \mathrm{~km}$ scale) quantitative estimates of decay scale have been derived from remote sensing data of the real ocean system. In the case of the North Atlantic, it has been assumed that the unforced system is linear. The 3 year time scale can be compared with the time it takes for the surface waters to circulate in the $\mathrm{STG}, \sim 8$ years. In reality, buoyancy driven circulations with their associated heat fluxes will develop as the wind driven system closes down since the dynamic height in equatorial regions is higher than in polar regions. A related example is the enhanced poleward continental slope flow that develops along the west European ocean margin under extreme negative NAO conditions. The 1995/1996 negative NAO conditions resulted in a marked winter west European poleward continental slope current bringing warm water northward along the shelf edge and a reduced North Atlantic clockwise circulation as a result of the reduced wind stress curl magnitude (see Pingree, 2002). The 1996 effects are widespread and can be observed in altimeter data in other places. In the north-west Atlantic, Labrador Subarctic Slope Water advanced equatorward along the shelf break as far as the Middle Atlantic Bight in 1998 (Greene \& Pershing, 2003). It is noted that NAO correlation lags based on temperature change will be longer than the more direct responses based on currents as an advective temperature change relates to the time integrated current strength or the amount of water transported (see also comments in Results).

To examine possible climate linkages across different regions and significance, sea level elevation changes for the North Atlantic Ocean were examined on time scales from $\sim 100$ days to eight year periodicity using altimeter data to derive the Fourier (amplitude and phase) components. The semi-annual amplitude structure was significant in the eastern Equatorial region, the Gulf of Mexico and the Gulf Stream region. Annual amplitude structure is given in Pingree \& Garcia-Soto (2004) and is most intense in the Gulf Stream region. Two year periodicity was also evident in the Gulf Stream region. Four year periodicity was more intense in parts of the STG with a further maximum amplitude structure centred in the Caribbean. Eight year periodicity was more intense in the Gulf Stream region and linked to subpolar regions (Figure 7). Values $>3 \mathrm{~cm}$ followed the course of the $\mathrm{NAC}$ to the Norwegian Basin and to the westward branch of the NAC or the Irminger Current and the West Greenland Current. However, this structure was not clearly connected to the Florida Current. The region of minimum sea level elevation amplitude $\sim<1 \mathrm{~cm}$ (and also minimum gradient) or near stagnant zone for the eight year periodicity is just south of the STG axis $\left(\sim 30^{\circ} \mathrm{N}\right)$, near $\sim 25^{\circ} \mathrm{N}$ in a central Atlantic region. This region overlaps the region of minimum mean concentration of SeaWiFS chlorophyll- $a$ or the oligotrophic chlorophyll low of the North Atlantic Ocean, with a minimum value $\left(\sim 0.06 \mathrm{mg} \mathrm{m}^{-3}\right)$ at $25^{\circ} \mathrm{N}$ $63^{\circ} \mathrm{W}$ in the Sargasso Sea. This region of minimum concentration levels of phytoplankton standing crop results from the lack of a significant connective nutrient flux with northern (or equatorial) regions. The nutrient poor surface Subtropical Water tends to recirculate with downward Ekman pumping. It was shown that a parcel of water at $26^{\circ} \mathrm{N}$, in the oligotrophic chlorophyll- $a$ low subducts at $40 \mathrm{my}^{-1}$ (Pingree, 1996). In 2008, there will be sufficient altimeter data to determine the structure of the 16 year Fourier component or climate change signal which may show a more obvious altimeter data connection between the Caribbean and the North Atlantic Current. It will be also be possible to assess the significance of the single estimate of the eight year component presented. A chance distribution seems unlikely (see also the NAC and NAO Index correlations (Figure 6)) since the distribution of the amplitude structure is consistent with recognized oceanographic conditions. For dynamic interpretation of the longer term amplitude structure (Figure 7), account of phase needs to be taken into consideration and since the maximum amplitude $(\sim>1 \mathrm{~cm})$ west of Africa is partially out of phase with the maximum amplitude $(\sim>3 \mathrm{~cm})$ in the Gulf Stream/ NAC region, the minimum amplitude region $(\sim<1 \mathrm{~cm})$ tends to result in a monotonic surface elevation change across the region or a tendency for a pivoting region or hinge line. The phase for the maximum amplitude region west of Africa and south of Iceland and Greenland is such that sea elevation is most raised in 1996/1997 or geostrophically indicating large scale cyclonic ocean margin conditions with respect to the ocean. This effect is just evident along the eastern boundary in Figure 1 (3 June 1996; and other sla maps, 26 December 1995, 15 December 1997, for example) 
despite the mesoscale variability and this time window falls in the general period of negative winter NAO Index (Figure 5) when the North Atlantic circulation would be expected to become less anticyclonic.

\section{North Sea}

For appraisal of conditions for the shelf seas around the British Isles (e.g. North Sea) both local forcing (local currents and climatic conditions) and Atlantic inflow into the region must be considered. Since mean NAO conditions (Index $=0$ ) are approximately represented by southwest winds over the shelf seas around the British Isles (see for example, Smith (2001)), then mean wind stress distributions (e.g. Pingree \& Griffiths, 1980) will drive the longer term wind driven shelf sea currents. Winds from the north 'pushing' water into the North Sea do not result in a maximum transport inflow response for the northern North Sea. This is because a wind stress produces Ekman transports at right angles to the wind and a wind induced set-up. Stronger winds produce greater volume transports and state of the art hydrodynamic numerical models (e.g. Skogen \& Søiland, 1998) suggest that the transport into the North Sea is positively correlated with NAO Index. The winter inflow regions to the North Sea are warmer than the mean winter temperature for the North Sea and therefore winter NAO Index and North Sea winter temperature changes resulting from advection will tend to correlate positively. There are also climatic considerations which tend to result in cooler winters and cooler SST under NAO negative conditions so there will be an overall tendency for positive correlations of winter NAO Index and SST (say, February to June) in the North Sea (e.g. Kalnay et al., 1996; Woehrling et al., 2005). As well as wind driven inputs to the North Sea, there are currents that result from pressure gradients on the continental slopes with density and pressure fields forcing flow poleward. The continental slope flow enters the North Sea in the Fair Isle Channel $(\sim 100 \mathrm{~m}$ depth) and along the west side of the Norwegian Trench. This Atlantic flow does not penetrate the shallow water regions of the North Sea as it is steered topographically by geostrophy to flow in $(\sim 120 \mathrm{~m}$ depth contour between Shetlands and the Norwegian Trench) and then out along the Norwegian Trench (see for example, Pingree \& Le Cann, 1989). Similar general inflow regions occur when the shelf region is forced with a uniform south-west wind stress. A further smaller wind driven flow enters through the Strait of Dover, with warmer saltier properties that are significant for the temperature and salinity distributions in the Southern Bight of the North Sea. The outflow region for south-west wind driven transports is also along the Norwegian Trench (Figure 8). The maximum inflow or circulation response for the North Sea is for winds from the south-west $\left(\sim 228^{\circ} \mathrm{T}\right)$ and the wind driven system is linear with respect to applied wind stress, with a wind driven transport $\sim 6 \mathrm{~Sv} \mathrm{~Pa}^{-1}$. North Atlantic water entering the northern North Sea in winter (say, January and February) is warmer $\left(\sim 8^{\circ} \mathrm{C}\right.$, and saltier) than mean conditions in the North Sea or the temperature of water $\left(\sim 5.5^{\circ} \mathrm{C}\right)$ leaving the North Sea along the Norwegian Trench (Dietrich, 1962).
Observations from Lagrangian ARGOS buoys deployed in the NAC west of Ireland in 1989 and 1990 defined the path and strength of the NAC entering the northern region and gave typical mean flow values of $4 \mathrm{~km}$ a day in the Rockall Trough with values reaching $\sim 6 \mathrm{~km}$ a day along the edge of the Hebrides Shelf (Pingree, 1993). These flows cannot generally be adequately derived from regional models or CTD geostrophic sections and relevant ocean circulation patterns for this general region appear largely without adequate measurement or quantification (e.g. Reid et al., 1998). Holliday et al. (2000) show the northwards transport in the winter of 1990/1991 was $\sim-1 \mathrm{~Sv}$ to $+2 \mathrm{~Sv}$ in the vicinity of Anton Dohrn Seamount (near $57.5^{\circ} \mathrm{N}$ ), whereas direct Lagrangian measurements throughout January 1991 (near 59² $\mathrm{N}$ ) gave upper layer flows of $\sim 17 \mathrm{~cm} \mathrm{~s}^{-1}$ across a $\sim 200 \mathrm{~km}$ section oceanward from the shelf-break. Mean northward Lagrangian flow conditions in the Rockall Trough were found to be fairly uniform to depths of $\sim 570 \mathrm{~m}$ (except in baroclinic eddies) and so to depths of only $\sim 300 \mathrm{~m}$ a transport of $10 \mathrm{~Sv}$ is obtained for January 1991, comparable to the winter (1983/1984) estimates of Gould et al. (1985) at $61^{\circ} \mathrm{N}$ in the Faeroe Shetland Channel. Lagrangian measurements (924 buoy days) during 1989 and 1990 gave a mean northward component near $55^{\circ} \mathrm{N}$ of $3.7 \mathrm{~cm} \mathrm{~s}^{-1}$ (Pingree, 1993) which equates to a mean northern transport of $\sim 6 \mathrm{~Sv}$ (for $<600 \mathrm{~m}$ depth) for the Rockall Trough region. Seasonality is marked and northern transport or flow is a maximum in January (Gould et al., 1985) and this was confirmed using altimeter data. Altimeter surface elevation differences between the Hebridean Shelf and the adjacent ocean showed a weak correlation between the geostrophic current (NAG) and NAO Index with $r=0.35, r^{2}=0.12$ at a lag of $\sim 1$ year (or about 7 months after the $35^{\circ} \mathrm{W}$ NAC change (see Figures $3 \& 6$ )). The altimeter data showed little or no evidence for any increased geostrophic flow during 1996-1998 period, thought to relate to the ecosystem change in the North Sea near 1997 (Holliday \& Reid, 2001). The seasonal maximum in the strength of the NAG occurred at the end of December $(\sim 27$ December) for the nine year data time series. January SST in this region (at $\sim 59^{\circ} \mathrm{N} 9^{\circ} \mathrm{W} ; 2^{\circ}$ latitude by $2^{\circ}$ longitude averaging, 1982-2002) was not significantly positively correlated with winter $\mathrm{NAO}$ index for lags up to two years. The winter minimum SST (at $\sim 59^{\circ} \mathrm{N} 9^{\circ} \mathrm{W}$ ) and winter NAO Index gave negative correlations $(r=\sim-0.3)$. The winter minimum temperature of 1998 $\left(9.65^{\circ} \mathrm{C}\right.$, February) was the warmest since 1959 (also $9.65^{\circ} \mathrm{C}$, January) and the extent of the warmer 1998 water along the ocean margin from Spain to Scotland under negative NAO conditions is discussed in GarciaSoto et al. (2002). In January 1991, the flow over a $500 \mathrm{~km}$ length of the West Shetland Shelf (Argos buoy 3909) was $25 \mathrm{~km}$ a day. However, only part of this shelf edge flow with ocean properties subsequently enters the northern North Sea, most cuts across the North Sea or deflects across the Norwegian Trench to join the Norwegian Current. Both Argos buoys 5029 and 3909 which travelled along the West Shetland Shelf (from north of the Hebrides), north around the Shetland Isles and across the northern North Sea to Norway (at an average surface speed of $22 \mathrm{~cm} \mathrm{~s}^{-1}$ ) deflected in and out of the entrance of 
the Norwegian Trench (5029 in September 1989 and 3909 in February 1991; see also Poulain et al., 1996).

The correlation lag between NAO and SST for North Sea temperature will depend partly on position since there are three main inflow regions. The temperature changes in the central North Sea $\left(53^{\circ} \mathrm{N} 3{ }^{\circ} \mathrm{E}\right)$ in the vicinity of the Dogger Bank in the winter to spring season are mainly considered as in the summer to winter period the mean spatial temperature gradients reverse with warmer SST water downstream (from the north-west). Changes in the inflow temperature resulting from the Continental Slope Current (Pingree et al., 1999), such as occurred in 1996 (with January inflow boundary temperatures of $9^{\circ} \mathrm{C}\left(1^{\circ} \mathrm{C}\right.$ above average) with negative NAO Index, Garcia-Soto et al. (2002)) and in 1998 (MBA News, October 2004), will tend to weaken the correlation response as will warming or changes of temperature of inflow water unrelated to NAO changes. The wind direction over the North Sea tends to be more southerly (or south-easterly) when the NAO Index is strongly negative and these wind directions result in less inflow for the same wind stress. Indeed, it is the response difference between south-west winds and south-east winds (as well as wind strength) that largely determines the winter advective heat flux. In Pingree \& Griffiths (1980), the continental shelf wind-driven water net transports $\left(\mathrm{Sv}_{\mathrm{v}} \times 100\right)$ across the Strait of Dover, $Q_{d}$, and through the Fair Isle Channel, $Q_{\mathrm{f}}$, into the North Sea were given as

$Q_{\mathrm{d}}=12 \cos \left(\theta-187^{\circ}\right)$ per unit wind stress $\left(\right.$ dynes $\left.\mathrm{cm}^{-2}\right)$ $\mathrm{Q}_{\mathrm{f}}=33 \cos \left(\theta-202^{\circ}\right)$ per unit wind stress.

The outflow $Q_{\text {out }}$ in the Norwegian Trench (at $59.5^{\circ} \mathrm{N}$ ) was given as

$Q_{\text {out }}=60 \cos \left(\theta-228^{\circ}\right)$ per unit wind stress.

Substituting for south-west wind, $\theta=225^{\circ}$, gives $\mathrm{Q}_{\mathrm{d}}$ $=0.9 \mathrm{~Sv} \mathrm{~Pa}^{-1}, \mathrm{Q}_{\mathrm{f}}=3.0 \mathrm{~Sv} \mathrm{~Pa}^{-1}, \mathrm{Q}_{\text {out }}=6.0 \mathrm{~Sv} \mathrm{~Pa}{ }^{-1}$ and for south-east $\quad \theta=135^{\circ} \quad$ gives $\quad \mathrm{Q}_{\mathrm{d}}=0.7 \mathrm{~Sv} \mathrm{~Pa}^{-1}$, $Q_{\mathrm{f}}=1.3 \mathrm{~Sv} \mathrm{~Pa}^{-1}, \quad \mathrm{Q}_{\text {out }}=0.3 \mathrm{~Sv} \mathrm{~Pa}^{-1}$. The south-west (NAO positive) winds give a maximum wind driven flow through the North Sea and out along the Norwegian Trench. The south-east wind response (tendency with extreme NAO negative conditions), which is in quadrature with the south-west wind response, results in only $\sim 10 \%$ of the flow through the North Sea, since the shelf driven flow entering through the Fair Isle Channel and any inflow between the Shetland Isles and Norway does not penetrate the region but is instead directed out of the northern North Sea between the Shetland Isles and the Norwegian Trench resulting in little net transport, leaving only that passing through the Strait of Dover to flow through the southern region. Moreover, the winter temperature of the warm water tongue in the Southern Bight of the North Sea emanating from the eastern English Channel through the Strait of Dover is about $0.5-1{ }^{\circ} \mathrm{C}$ cooler than the northern inflow region in January, February and March so the relative warming response for a south-east condition is further reduced. For the positive NAO winter conditions of 1994/ 1995, the mean isobars were directed for south-west winds and the atmospheric pressure difference across the North Sea region was about 20 mbar. For the extreme NAO negative winter conditions of 1995/1996, the isobars indicated a mean south-south-east wind tendency with about 6 mbars across the region. In terms of wind stress, the positive NAO south-west stress conditions might be expected to be an order of magnitude larger in 1994/1995 (winter) than 1995/1996 (winter). Overall, the winter advective heat supply to the North Sea turns off in extreme negative winter NAO conditions with south-east winds (or windless conditions).

The mean south-west wind field over the shelf region (i.e water depths $<\sim 180 \mathrm{~m}$ along the western shelf) gives a mean North Sea shelf circulation net transport of $\sim 1 \mathrm{~Sv}$, leaving the Norwegian Trench (section at $59.5^{\circ} \mathrm{N}$ ), and the mean advective heat supply rate over the winter (January, February, March) months is $\sim 1-2$ tera cal s ${ }^{-1}$. Applying the upper estimate to the area of the North Sea (for water depths $<200 \mathrm{~m}$ ) gives an equivalent surface heat flux of $\sim 1080 \mathrm{cal} \mathrm{cm}^{-2} \mathrm{month}^{-1}$, or a $0.5^{\circ} \mathrm{C}$ warming of a $65 \mathrm{~m}$ water column $(64.7 \mathrm{~m}$ is the mean depth of the North Sea, including the Skagerrak and Kattegat for water depths $<200 \mathrm{~m}$ taking into account water depth datum) resulting from the three month winter warming period. The volume for this region $(<200 \mathrm{~m})$ is $3.14 \times 10^{13} \mathrm{~m}^{3}$ so an average flushing or residence time for this mean depth region (65 $\mathrm{m}$ ) is $\sim 363$ days. Thus it will take about one year for concentration levels (temperature, plankton) associated with the near North Atlantic to become fully established in the central and southern North Sea. For an example of southern influence, we consider the North Atlantic section of $35^{\circ} \mathrm{W}$ (Figure 1). From this region, a particle in the NAC could on average take $\sim 5$ months to reach a position near $52^{\circ} \mathrm{N} 21.5^{\circ} \mathrm{W}$ (four drogued ARGOS buoys deployed in NAG) and then a further $\sim 7$ months to move along the Rockall Trough to arrive in the vicinity of the West Shetland Shelf. So if a marked NAO Index change results in a change of NAC at $35^{\circ} \mathrm{W}$ which then results in a movement of a fixed (i.e. without further propagation by growth or local source) change of water properties, it could be $\sim 2-3$ years (after the NAO change) before these concentration effects are fully experienced throughout the North Sea.

The correlation response for monthly sea-surface temperature values against NAO Index in the vicinity of the Dogger Bank $\left(55^{\circ} \mathrm{N} 3^{\circ} \mathrm{E}\right.$, mean water depth $\left.\sim 40 \mathrm{~m}\right)$ in the southern North Sea has a maximum value of $r^{2} \sim 0.1$ at a lag of about $4-5$ months for the same data time window considered for the NAC (Figure 6, Table 1). Overall, the correlation values $r \sim 0.3$ are not large (but opposite sign to the north-west of Hebrides region, $\sim 59^{\circ} \mathrm{N} 9^{\circ} \mathrm{W}$ ) but selection of years with extreme NAO Index values shows that changes can be particularly marked. Maximum average temperatures occurred during the period from 1989 to 1995 (inclusive) over the 50 year period considered, when the mean NAO Index was also a maximum (NAO winter Index $\sim+3$ ) over the last $\sim 100$ years, with maximum wind stress inflow. When the south-westerly winds stop, the North Sea wind driven circulation closes down. An $\mathrm{e}^{-1}$ decay time scale (using a mean depth of $\sim 50 \mathrm{~m}$, and $50 \mathrm{~m}$ is the mean depth of the North Sea region including the Skagerrak and Kattegat with water depth $<100 \mathrm{~m}$ ) for the central and southern North Sea currents is $\sim 1$ day. The mean temperature in the North Sea $\left(55^{\circ} \mathrm{N} 3^{\circ} \mathrm{E}\right)$ for years with negative index falls with respect to those years with a positive index by 
$\sim 1.0^{\circ} \mathrm{C}$ for the 4-year example given (Table 1, 1936, 1963, 1969 and 1996).

Direct in situ measurements of currents are particularly valuable for the climate change year of 1996. On yearday 71 (11 March, 1996), Argos buoy 3350 (drogue at $45 \mathrm{~m}$ ) was on the continental shelf, just north of the Shetland Isles at $60.6^{\circ} \mathrm{N} 2.0^{\circ} \mathrm{W}$. On yearday 211,140 days later $(29$ July, 1996), buoy 3350 was at $60.6^{\circ} \mathrm{N} 1.8^{\circ} \mathrm{E}$, having moved eastward $\sim 208 \mathrm{~km}$ across the northern North Sea at a mean speed of $1.5 \mathrm{~km} \mathrm{~d}^{-1}$ (Pingree et al., 1999). The track shows that the flow entering the northern shelf region of the northern North Sea between the Shetland Isles and the Norwegian Trench largely stopped in 1996 under the extreme negative NAO conditions. The North Sea temperature (at $55^{\circ} \mathrm{N} 3^{\circ} \mathrm{E}$ ) fell to $3.1^{\circ} \mathrm{C}$ in March 1996, the coldest recorded winter temperature since 1888. This value $\left(3.1^{\circ} \mathrm{C}\right)$ can be compared to the winter minimum value of $7.4^{\circ} \mathrm{C}$ in March 1990 (following large positive winter NAO Index values, Figure 2), and this was the highest recorded March winter temperature since records began (1848). The mean North Sea temperature $\left(\right.$ at $55^{\circ} \mathrm{N}$ $3^{\circ} \mathrm{E}$ ) fell to $9.1^{\circ} \mathrm{C}$ in 1996 (cf. 50 year mean $10.1^{\circ} \mathrm{C}$ ). The summary temperatures given in Table 1 also show that the seasonal amplitude is damped by $\sim 2^{\circ} \mathrm{C}$ (range) in years with marked positive conditions with respect to negative conditions and that the seasonal cycle or annual component is delayed by one week under such negative conditions. Maximum summer temperatures $\left(\right.$ at $55^{\circ} \mathrm{N} 3^{\circ} \mathrm{E}$ ) are much the same $\left(15.4^{\circ} \mathrm{C}\right.$, just considering the annual component and the period mean temperature) but winter temperatures are on average colder by $2^{\circ} \mathrm{C}$ under extreme negative conditions (NAO winter Index $\sim-4.0$ ) under continental influence without the oceanic winter warming and the winter minimum (which is also colder) is reached a week later (25 February) than in conditions of marked positive index (18 February).

It is clear that advective heat fluxes are not sufficient to explain the full changes of temperature that occur in the North Sea in the more central regions, with temperatures in NAO positive winter conditions $2^{\circ} \mathrm{C}$ above NAO negative conditions as early as mid February (Figure 9). When temperatures values for individual months are correlated against lagged monthly NAO values (Table 2) it is evident that even for zero lag, January and February fluctuations of temperature and NAO Index correlate positively. Furthermore, the maximum correlation (significance $\sim<0.05)$ for any lags $(0-5$ months $)$ reflects February NAO Index conditions (see Table 2). This implies meteorological conditions in January/February controlling surface heat fluxes, air-sea interaction and local SST change. For example, in the positive winter NAO conditions of 1994/1995, climatic conditions over the North Sea were wetter than normal and warmer air temperature conditions extended from North Africa to Siberia. In the winter NAO negative phase of 1995/1996, the North Sea was under the influence of drier and cooler conditions with higher atmospheric pressure over Europe and Siberia (which resulted in the southerly to southeasterly tendency of the wind field over the North Sea as discussed above). These effects on heat transfer, particularly longwave radiation loss, will enhance winter cooling and result in a lower winter (February) minimum temperature for the North Sea.

\section{Seasonality, ocean colour, $\mathcal{N} A O$}

Seasonal advance, or delay time to reach a given temperature, can be particularly important for biological systems if growth depends on temperature (Edwards \& Richardson, 2004) or if a specific temperature level works as a zeitgeber for a particular response or development. Increases in temperature will also affect biogeographical boundaries or northern and southern limits for warm and cold water species. On the continental shelf, shallow-water depths and continental climate influences of adjacent land masses result in larger annual temperature ranges than occur in oceanic environments. For the North Sea $\left(55^{\circ} \mathrm{N} 3^{\circ} \mathrm{E}\right)$, the seasonal temperature range is $\sim 11^{\circ} \mathrm{C}$ and the timing difference, for winter $\mathrm{NAO}$ negative years with respect to positive years, to reach a fixed temperature in the spring can amount to a month (Table 1). The SST values of $7^{\circ} \mathrm{C}$ occur near the end of March under winter NAO positive $(\sim+3)$ conditions but occur near the start of May following winter NAO negative $(\sim-4)$ conditions (Figure 9, Appendix 1). The NAC at $51.5^{\circ} \mathrm{N}\left(22^{\circ} \mathrm{W}\right)$ and the STG at $26^{\circ} \mathrm{N}$ both have a seasonal temperature range of $\sim 4^{\circ} \mathrm{C}$. Lower annual amplitudes in oceanic conditions with respect to continental shelf conditions result in a relatively larger seasonal advance for oceanic temperature as the annual mean surface temperatures increase with global warming (Appendix 1).

The oceanic regions of the northern Bay of Biscay (temperature range $\sim 7^{\circ} \mathrm{C}$ ) are about $1^{\circ} \mathrm{C}$ warmer than 100 years ago with a warm period near 1960 (Southward et al., 2005). The spring $12^{\circ} \mathrm{C}$ SST comes about three weeks earlier than it did 100 years ago. However, for the development of the spring phytoplankton bloom, small differences in near-surface temperature with respect to depth (z) controlling light levels, $\Delta \mathrm{T}(\mathrm{z})$, rather than temperature itself initiate the start of the bloom outburst. Values of $\Delta \mathrm{T}(\mathrm{z})=0.1^{\circ} \mathrm{C}$ are significant on the continental shelf, except in shallow regions where the euphotic depth for net production exceeds the water depth. In 1975, the spring bloom started on 12 April in the Celtic Sea (Pingree et al., 1976) in parallel with a developing seasonal thermocline with surface to bottom temperature differences of $\sim 0.2^{\circ} \mathrm{C}$. In the northern Bay of Biscay in 1989, marked increases in surface chlorophyll- $a$ (chl- $a$ ) levels were observed on 28 April (with SST near $12^{\circ} \mathrm{G}$ ) and these increased levels of chlorophyll- $a$ were related to seasonal thermocline development. Values of $\Delta \mathrm{T}(\mathrm{z})=0.15^{\circ} \mathrm{C}$ over the upper $100 \mathrm{~m}$ of the water column occurred with vertically integrated chlorophyll levels of $221 \mathrm{mg}$ chl- $a \mathrm{~m}^{-2}$ (Garcia-Soto \& Pingree, 1998). Spatial and temporal regime shifts, both biological and physical, may occur with increasing temperature but if caused directly by NAO Index inducing NAC flow structure or change (Figure 2 ) could only occur $\sim>6$ months after a significant NAO change, after the winter of 1988/1989, for example, or after 1996 as shown by Greene \& Pershing (2003) or after 2000 for the 20 year period (Figure 2) considered in this paper. The PCI regime shift $\sim 1985-$ 1990 of Reid et al. (2001) (also shown for total dinoflagellate abundance, Leterme et al., 2005; see also Raitsos et al., 2005) appears to show little phase lag with respect to SSTor NAO and may even be slightly advanced, so, if significant, correlations might reflect a common effect rather than a causal link. 
Maximum summer shelf temperatures in stratified conditions occur under sunny conditions with little wind. In the stratified waters of the western English Channel, marked blooms of dinoflagellates (brown water) and coccolithophores (white water, e.g. Garcia-Soto et al., 1995) can occur in summer (June, July, August) on the northern side of the Channel where tidal mixing is reduced. Marked dinoflagellate blooms in the western English Channel (Pingree et al., 1977) were in part related to shallow thermocline formation with reduced mixed layer depths under settled calm weather conditions e.g. July 1975 and July/August 1976 (monthly NAO Index $\sim-3.0$ ) and July 2000 (monthly NAO Index $\sim-2.9$ ) at E1 in the English Channel. The intensity of these summer blooms, where chlorophyll- $a$ levels can be in excess of $100 \mathrm{mg}$ chl- $a \mathrm{~m}^{-3}$, can change the mean (over the data series) seasonal cycle of phytoplankton chlorophyll- $a$ from a dominant spring (April) peak to a dominant summer (July, August) peak (e.g. E1, Figure 10A). Hence, on shorter timescales, surface concentrations of phytoplankton (or SST) and monthly NAO Index may correlate inversely in oceanic regions or deeper shelf regions that stratify in spring or early summer. In summary, large positive NAO index conditions (or rather increased wind strength and mixing) at the start of the productive season result in lower surface chlorophyll- $a$ values. Large negative NAO monthly values in the summer are associated with increased seasonal stratification, shallower mixed depths, rising temperatures and higher surface dinoflagellate phytoplankton concentrations. A lag of about 1-2 weeks might be anticipated or zero lagged monthly values for maximum correlations. These effects can be visualized on a large scale by observing the monthly North Atlantic $\left(35^{\circ} \mathrm{N}-55^{\circ} \mathrm{N}\right.$ ) SeaWiFS concentrations for 2002 (associated with positive monthly NAO Index values, e.g. April 2.2, May 1.9, June 1.9, July 1.6). Measurements along $\sim 20^{\circ} \mathrm{W}\left(\sim 41^{\circ} \mathrm{N}-54^{\circ} \mathrm{N}\right.$, across the deep winter mixing region near $47^{\circ} \mathrm{N}$, Pingree (1997)) in April 1989 (GarciaSoto \& Pingree, 1998) following windy conditions in March and April, showed that although the surface chlorophyll- $a$ values were low (generally $<\sim 0.3 \mathrm{mgchl}-a \mathrm{~m}^{-3}$ ), concentrations of $\sim 0.2 \mathrm{mg}$ chl- $a \mathrm{~m}^{-3}$ were mixed to depth $(\sim 250 \mathrm{~m})$, resulting in significant vertically integrated values $\left(\sim 75 \mathrm{mg}\right.$ chl- $\left.a \mathrm{~m}^{-2}\right)$ at mid positions $\left(\sim 47^{\circ} \mathrm{N}\right)$ along the section. In like manner, it is noted that the 2002 SeaWiFS spring bloom (at the surface or to $\sim$ optical depth) in this region $\left(\sim 48^{\circ} \mathrm{N}\right.$ $20^{\circ} \mathrm{W}$ ) was largely absent with April, May, June and July concentrations (during the monthly NAO Index positive conditions) less than half the surface monthly mean levels (Figure 10B).

Gridded processed altimeter data were received from AVISO Altimetry/CLS Space Oceanography Division, Toulouse, France. COADS 2-degree enhanced data were obtained from NOAA-CIRES Climate Diagnostics Center (Boulder, Colorado, USA). NAO winter and monthly index data were taken from www.cgd.ucar.edu/cas/jhurrell/nao.stat.winter.html. SeaWiFS data were supplied from the Goddard Earth Science Data and Information Services Center, Greenbelt, USA. In situ measurements of flow and North Atlantic SST were obtained from Ocean Climate (ARGOS 780). Sophie Leterme (SAHFOS, University of Plymouth) kindly provided the analyses for Table 2.

\section{REFERENCES}

Bower, A.S. et al., 2002. Directly measured mid-depth circulation in the northeastern North Atlantic Ocean. Nature, London, 419, 603-607.

Cromwell, D. \& Smeed, D.A., 1998. Altimetric observations of sea level cycles near the Strait of Bab al Mandab. International Journal of Remote Sensing, 19, 1561-1578.

Dietrich, G., ed., 1962. Mean Monthly Temperature and Salinity of the Surface Layer of the North Sea and Adjacent Waters from 1905-1954. Charlottenlund Slot, Denmark: Conseil Permanent International pour l'Exploration de la Mer, Service Hydrographique.

Edwards, M. \& Richardson, A., 2004. Impact of climate change on marine pelagic phenology and trophic mismatch. Nature, London, 430, 881-884.

Fuglister, F.C., 1960. The Atlantic Ocean Atlas of temperature and salinity profiles and data from the International Geophysical Year of 1957-1958. Woods Hole Oceanographic Institution Atlas Series, 1, 1-209.

Garcia-Soto, C., Fernandez, E., Pingree, R.D. \& Harbour, D.S., 1995. Evolution and structure of a shelf coccolithophore bloom in the Western English Channel. Journal of Plankton Research, 17, 2011-2036.

Garcia-Soto, C. \& Pingree, R.D., 1998. Late autumn distribution and seasonality of chlorophyll- $a$ at the shelfbreak/slope region of the Armorican and Celtic Shelf. Fournal of the Marine Biological Association of the United Kingdom, 78, 17-33.

Garcia-Soto, C., Pingree, R.D. \& Valdes, L., 2002. Navidad development in the southern Bay of Biscay: climate change and swoddy structure from remote sensing and in situ measurements. Fournal of Geophysical Research, 107, 1-29.

Gould, W., Loynes, J. \& Backhaus, J., 1985. Seasonality of slope transports NW of Shetland. International Council for the Exploration of the Sea (CM Papers and Reports), C: 7, 7 pp.

Greene, C.H. \& Pershing, A.J., 2003. The flip-side of the North Atlantic Oscillation and modal shifts in slope-water circulation patterns. Limnology and Oceanography, 48, 319-322.

Griffiths, G. et al., 1992. CTD oxygen, tracer and nutrient data from RRS Charles Darwin Cruises 58/59 in the NE Atlantic as part of Vivaldi '91. Institute of Oceanographic Sciences Deacon Laboratory, Report, no. 296, 51 pp.

Holliday, N.P., Pollard, R.T., Read, J.F. \& Leach, H., 2000. Water mass properties and fluxes in the Rockall Trough, 19751998. Deep-Sea Research 1, 47, 1303-1332.

Holliday, N.P. \& Reid, P.C., 2001. Is there a connection between high transport of water through the Rockall Trough and ecological changes in the North Sea? ICES Fournal of Marine Science, 58, 270-274.

Hydrographic Department, 2002. Charts 5124 (1) to (12). Taunton: Hydrographic Office.

Kalnay, E. et al., 1996. The NCEP/NCAR 40-year reanalysis project. Bulletin of the American Meteorological Society, 77, 437-471.

Krauss, W., 1986. The North Atlantic Current. Fournal of Geophysical Research, 91, 5061-5074.

Lavin, A.M., Bryden, H.L. \& Parrilla, G., 2003. Mechanism of heat, freshwater and nutrient transports and budgets at $24.5^{\circ} \mathrm{N}$ in the subtropical North Atlantic. Deep-Sea Research 1, 50, 1099-1128.

Leterme, S.C., Edwards, M., Seuront, L., Attrill, M.J., Reid, P.G. \& John, A.W.G., 2005. Decadal basin-scale changes in diatoms, dinoflagellates, and phytoplankton color across the North Atlantic. Limnology and Oceanography, 50, $1244-1253$.

Le Traon, P.Y., Nadal, F. \& Ducet, N., 1998. An improved mapping method of multi-satellite altimeter data. Fournal of Atmospheric and Oceanic Technology, 15, 522-534. 
Levitus, S. \& Boyer, T.P., 1994. World Ocean Atlas 1994. Washington DC: National Oceanographic Data Centre.

Ocean Circulation, 2001. Second edition, Butterworth Heinemann Publishers, 286 pp.

Ocean Zone, 2003. Issue 9, published by Southampton Oceanography Centre, 4 pp.

Pingree, R.D., 1993. Flow of water to the west of the British Isles and in the Bay of Biscay. Deep-Sea Research 11, 40, 369-388.

Pingree, R.D., 1996. A shallow subtropical subducting westward propagating eddy (swesty). Philosophical Transactions of the Royal Society A, 354, 979-1026.

Pingree, R.D., 1997. The Eastern Subtropical Gyre (North Atlantic): Flow Rings Recirculation Structure and Subduction. Fournal of the Marine Biological Association of the United Kingdom, 77, 573-624.

Pingree, R.D., 2002. Ocean structure and climate (Eastern North Atlantic): in situ measurement and remote sensing (altimeter). Fournal of the Marine Biological Association of the United Kingdom, 82, 681-707.

Pingree, R.D. \& Garcia-Soto, C., 2004. Annual westward propagating anomalies near $26^{\circ} \mathrm{N}$ and eddy generation south of the Canary Islands: remote sensing (altimeter/SeaWiFS) and in situ measurement. Fournal of the Marine Biological Association of the United Kingdom, 84, 1105-1115.

Pingree, R.D. \& Griffiths, D.K., 1980. Currents driven by a steady uniform wind stress on the shelf seas around the British Isles. Oceanologica Acta, 3, 227-236.

Pingree, R.D., Holligan, P.M. \& Head, R.N., 1977. Survival of dinoflagellate blooms in the western English Channel. Nature, London, 265, 266-269.

Pingree, R.D., Holligan, P.M., Mardell, G.T. \& Head, R.N., 1976. The influence of physical stability on spring, summer and autumn phytoplankton blooms in the Celtic Sea. Fournal of the Marine Biological Association of the United Kingdom, 56, 845-873.

Pingree, R.D., Kuo, Y.-H. \& Garcia-Soto, C., 2002. Can the Subtropical North Atlantic Ocean permanent thermocline be observed from space? Fournal of the Marine Biological Association of the United Kingdom, 82, 709-728.

Pingree, R.D. \& Le Cann, B., 1989. Celtic and Armorican slope and shelf residual currents. Progress in Oceanography, 23, 303338.

Pingree, R.D. \& Le Cann, B., 1991. Drifting Buoy in the Field of Flow of Two Eddies on East Thulean Rise (Northeast Atlantic). Journal of Geophysical Research, 96, 16 759-16 777.

Pingree, R.D., Sinha, B. \& Griffiths, C.R., 1999. Seasonality of the European slope current (Goban Spur) and ocean margin exchange. Continental Shelf Research, 19, 929-975.

PML, 1994. RRS Charles Darwin Cruise 83 Report, 13 December 1993-13 January 1994. Plymouth Marine Laboratory, 91 pp.

Pollard, R.T., Griffiths, G., Cunningham, S., Read, J.F., Perez, F.F. \& Rios, A.F., 1996. Vivaldi 1991 — a study of the formation, circulation and ventilation of the Eastern North Atlantic Central Water. Progress in Oceanography, 37, 167-192.

Poulain, P.-M., Warn-Varnas, A. \& Niiler, P.P., 1996. Nearsurface circulation of the Nordic seas as measured by Lagrangian drifters. Fournal of Geophysical Research, 101, 18 23718258.

Raitsos, D.E., Reid, P.C., Lavender, S.J., Edwards, M. \& Richardson, A.J., 2005. Extending the SeaWiFs chlorophyll data set back 50 years in the northeast Atlantic. Geophysical Research Letters, 32, L06603, 4 pp. rapidmoc, 2004. Gulf Stream probed for early warnings of system failure. Nature, London, 427, 769.

Reid, P.C., Borges, M.F. \& Svendsen, E., 2001. A regime shift in the North Sea circa 1988 linked to changes in the North Sea horse mackerel fishery. Fisheries Research, 50, 163-171.

Reid, P.C., Planque, B. \& Edwards, M., 1998. Is the observed variability in the Continuous Plankton Recorder survey a response to climate change? Fisheries Oceanography, 7, 282-288.

Richards, P., 2002. Westward propagating disturbances at $26^{\circ} \mathcal{N}$ in the Subtropical North Atlantic using altimeter remote sensing data from ERS1/2 and TOPEX POSEIDON satellites. Plymouth: Department of Mathematics and Statistics, University of Plymouth.

Richardson, P.L., 1985. Drifting derelicts in the North Atlantic 1883-1902. Progress in Oceanography, 14, 463-483.

Roemmich, D. \& Wunsch, C., 1985. Two transatlantic sections: meridional circulation and heat flux in the subtropical North Atlantic Ocean. Deep-Sea Research 1, 32, 619-664.

Schott, F. \& Stommel, H., 1978. Beta-Spirals and absolute Velocities in Different Oceans. Deep-Sea Research, 25, 961-1010.

Skogen, M. \& Søiland, H., 1998. A user's guide to NORWECOM v2.0. The Norwegian ECOlogical Model system. Technical Report Fisken og Havet 18/98. Institute of Marine Research, Pb.1870, N-5024 Bergen, 42 pp.

Smith, P.C., Houghton, R.W., Fairbanks, R.G. \& Mountain, D.G., 2001. Interannual variability of boundary fluxes and water mass properties in the Gulf of Maine and on Georges Bank: 1993-1997. Deep-Sea Research 11, 48, 37-70.

Southward, A.J. et al., 2005. Long-Term Oceanographic and Ecological Research in the Western English Channel. Advances in Marine Biology, 47, 1-105.

Srokosz, M.A., 2003. Rapid climate change: scientific challenges and the new NERC programme. Philosophical Transactions of the Royal Society A, 361, 2061-2078.

Stanhill, G. \& Cohen, S., 2001. A Review of the Evidence. Agricultural and Forest Meteorology, 107, 255-278.

Stommel, H., 1987. A View of the Sea. Princeton: Princeton University Press.

UK WOGE. Understanding Ocean Circulation, Natural Environment Research Council (ed. R.T. Pollard and D. Smythe-Wright), $32 \mathrm{pp}$.

Weller, R.A., Furey, P.W., Spall, M.A. \& Davis, R.E., 2004. The large-scale context for oceanic subduction in the Northeast Atlantic. Deep-Sea Research 1, 51, 665-699.

Woehrling, D., Lefebvre, A., Le Fèvre-Lehoërff, G. \& Delesmont, R., 2005. Seasonal and longer term trends in sea temperature along the French North Sea coast, 1975 to 2002. Fournal of the Marine Biological Association of the United Kingdom, 85, 39-48.

Wunsch, C., 2004. Gulf Stream safe if wind blows and Earth turns. Nature, London, 428, 601.

Zhou, M., Paduan, J.D. \& Niiler, P., 2000. Surface current in the Canary Basin from drifter observations. Fournal of Geophysical Research, 105, 21 893-21911. 


\section{APPENDIX 1}

A simple model of sea-surface temperature (SST), T, changes with respect to time, $t$, for the North Sea that accounts for $\sim 95 \%$ of the variance is

$\mathrm{T}(\mathrm{t})=\mathrm{T}_{\text {mean }}(\mathrm{t})+\mathrm{A}(\mathrm{t}) \cos (\omega \mathrm{t}-\phi(\mathrm{t}))$

where $\mathrm{T}_{\text {mean }}$ is the annual temperature or average temperature over a year. A is the annual amplitude, $\omega=2 \pi / \tau$, where $\tau$ is the annual period in days and $\phi$ is the phase lag with respect to 1 January (Table 1 ); $\mathrm{T}_{\text {mean }}, \phi$ and $\mathrm{A}$ are slowly (e.g. average value over one year) varying functions of time, $t$.

For comparing conditions in different years, or years with large positive North Atlantic Oscillation (NAO) Index and large negative index, the temperature difference is

$$
\begin{aligned}
\mathrm{T}^{+}\left(\mathrm{t}^{+}\right)-\mathrm{T}^{-}\left(\mathrm{t}^{-}\right)= & \mathrm{T}_{\text {mean }}^{+}+\mathrm{A}^{+} \cos \left(\mathrm{t}^{+}-\phi^{+}\right) \\
& -\mathrm{T}_{\text {mean }}^{-}-\mathrm{A}^{-} \cos \left(\mathrm{t}^{-}-\phi^{-}\right)
\end{aligned}
$$

where the positive superscripts refer to positive NAO Index years and negative superscripts refer to negative NAO Index years and for convenience time and $\phi$ are in degrees $\left(0^{\circ}\right.$ is 1 January). To see how long it takes to reach a given temperature in the year, or the temperature delay in cooler years with negative index with respect to positive years, $\mathrm{T}^{+}-\mathrm{T}^{-}$is set to zero. Equation 2 can be solved graphically by plotting the two cosine curves (Figure 9). For algebraic solution and first order approximation, we have

$\Delta \mathrm{T}+\mathrm{A}^{+} \cos \left(\mathrm{t}_{\mathrm{o}}\right)-\mathrm{A}^{-} \cos \left(\mathrm{t}_{\mathrm{o}}+\Delta \mathrm{t}-\delta\right)=0$

where $\Delta \mathrm{T}$ is the difference in the mean temperature and $\delta$ is the phase difference for the annual component between years of positive and negative NAO conditions. Time, $t_{0}$, is now measured with reference to the time of maximum temperature in positive NAO Index years. With timing difference, $\mathrm{t}^{-}-\mathrm{t}^{+}=\Delta \mathrm{t}$, and amplitude difference, $\mathrm{A}^{-}-\mathrm{A}^{+}=\Delta \mathrm{A}$, eqn (3) is rearranged as

$$
\begin{aligned}
& \Delta \mathrm{T}+\mathrm{A}^{+} \cos \left(\mathrm{t}_{\mathrm{o}}\right)-\left(\mathrm{A}^{+}+\Delta \mathrm{A}\right) \cos \left(\mathrm{t}_{\mathrm{o}}\right) \cos (\Delta \mathrm{t}-\delta) \\
& +\left(\mathrm{A}^{+}+\Delta \mathrm{A}\right) \sin \left(\mathrm{t}_{\mathrm{o}}\right) \sin (\Delta \mathrm{t}-\delta)=0
\end{aligned}
$$

or

$$
\begin{aligned}
& -\sin (\Delta \mathrm{t}-\delta)= \\
& \frac{\Delta \mathrm{T}+\mathrm{A}^{+} \cos \left(\mathrm{t}_{\mathrm{o}}\right)-\left(\mathrm{A}^{+}+\Delta \mathrm{A}\right) \cos \left(\mathrm{t}_{\mathrm{o}}\right) \cos (\Delta \mathrm{t}-\delta)}{\left(\mathrm{A}^{+}+\Delta \mathrm{A}\right) \sin \left(\mathrm{t}_{\mathrm{o}}\right)}
\end{aligned}
$$

Equation (5) can be solved by successive approximations for $\Delta \mathrm{t}$. For small $(\Delta \mathrm{t}-\delta) 2 \pi / 360$ and $\Delta \mathrm{A} / \mathrm{A}^{+}$, eqn (5) becomes,

$-(\Delta \mathrm{t}-\delta)=\frac{360\left(\Delta \mathrm{T}-\Delta \mathrm{A} \cos \left(\mathrm{t}_{\mathrm{o}}\right)\right)}{2 \pi\left(\mathrm{A}^{-}\right) \sin \left(\mathrm{t}_{\mathrm{o}}\right)}$
For illustrative purposes, representative of North Sea continental influence near the Dogger Bank (Table 1), we take

$$
\begin{aligned}
\mathrm{T}= & 10.5+5 \cos \left(\mathrm{t}-225^{\circ}\right) \text { for } \mathrm{NAO} \text { positive }(+3) \\
& \text { conditions } \\
\mathrm{T}= & 9.5+6 \cos \left(\mathrm{t}-232^{\circ}\right) \text { for NAO negative }(-4) \\
& \text { conditions }
\end{aligned}
$$

(and $\mathrm{T}=10.0+5.5 \cos \left(\mathrm{t}-228.5^{\circ}\right)$ for mean $\mathrm{NAO}=0$

conditions)

with phase values marginally adjusted for simplicity, $225^{\circ}$ equivalent to mid August and maximum temperature for NAO negative conditions one week (or $\delta=7^{\circ}$ ) later. For NAO positive conditions, the temperature, $\mathrm{T}=7.0^{\circ} \mathrm{C}$ on 1 April $\left(\mathrm{t}=90^{\circ}\right)$. Substituting, $\Delta \mathrm{T}=1.0^{\circ} \mathrm{C}, \mathrm{A}^{-}=6^{\circ} \mathrm{C}$, $\Delta \mathrm{A}=1.0^{\circ} \mathrm{C}, \mathrm{t}=90^{\circ} \quad(1$ April $), \mathrm{t}_{\mathrm{o}}=90^{\circ}-225^{\circ}, \delta=7^{\circ}$ in eqn (6) gives $\Delta t=+30^{\circ}$, or a month later (1 May) for the continental shelf NAO negative situation. At maximum temperature $\mathrm{t}=225^{\circ}$ (mid August), $\mathrm{T}=15.5^{\circ} \mathrm{C}$ and $\Delta \mathrm{t}=\delta=+7^{\circ}$ or a week later; for $\mathrm{T}=10.5^{\circ} \mathrm{C}, \mathrm{t}=135^{\circ}$ (mid May), $\mathrm{t}_{\mathrm{o}}=135^{\circ}-225^{\circ}, \Delta \mathrm{t}=+16.5^{\circ}$ or $\sim 2$ weeks later (see Figure 9).

For an oceanic situation, representative of SST for the northern Bay of Biscay $\left(\sim 48^{\circ} \mathrm{N}\right)$ with maximum temperature in September and minimum temperature of $\sim 11.0^{\circ} \mathrm{C}$ in mid March near the start of the 21st Century. Taking $\Delta \mathrm{T}=1.0^{\circ} \mathrm{C}$, for a $1^{\circ} \mathrm{C}$ warming over the last century, $\mathrm{A}=3.5^{\circ} \mathrm{C}, \Delta \mathrm{A}=0.0^{\circ} \mathrm{C}, \delta=0^{\circ}$, then for $\mathrm{t}=120^{\circ} \quad(1$ May, with $\mathrm{T}=12.0^{\circ} \mathrm{C}$ ), $\mathrm{t}_{\mathrm{o}}=120^{\circ}-255^{\circ}$ gives $\Delta \mathrm{t}=+23^{\circ}$, or a $\sim 23$ day advance for the present day season for a spring bloom temperature near $12^{\circ} \mathrm{C}$.

For the NAC (at $51.5^{\circ} \mathrm{N} 22^{\circ} \mathrm{W}$, e.g. Pingree \& Le Cann, 1991) or $26^{\circ} \mathrm{N}$ (e.g. Pingree, 1996) we take $\mathrm{A}=2.0^{\circ} \mathrm{C}$, $\Delta \mathrm{A}=0.0^{\circ} \mathrm{C}, \delta=0^{\circ}$ and assume there will be a $1^{\circ} \mathrm{C}$ increase of annual mean SST with $\Delta \mathrm{T}=1.0^{\circ} \mathrm{C}$ in the future. The present $(1989 / 1990) \mathrm{NAC}$ winter minimum at $51.5^{\circ} \mathrm{N}$ $22^{\circ} \mathrm{W}$ is $10.5^{\circ} \mathrm{C}(\sim \operatorname{mid} \mathrm{March})$ which increases to $11.5^{\circ} \mathrm{C}$ ( $\sim$ mid March) at some time in the future due to global warming. Presently, a temperature of $11.5^{\circ} \mathrm{C}$ is reached two months later in mid May (from eqn (1)). Near $\sim 26^{\circ} \mathrm{N}$, increases in SST of $\sim 1.3^{\circ} \mathrm{C}$ a year $\left(\sim 0.1^{\circ} \mathrm{C}\right.$ per month or $0.1^{\circ} \mathrm{C}$ per $100 \mathrm{~km}$ zonally) from March 1993 to September 1994 occurred as the measurement platform (ARGOS buoy) moved westward from $23^{\circ} \mathrm{W}$ to $42^{\circ} \mathrm{W}$. Hence, an overall spatial warming of SST of $1^{\circ} \mathrm{C}$ near $26^{\circ} \mathrm{N}$ moves the surface isotherms that might control biogeographical boundaries by $\sim 1000 \mathrm{~km}$ zonally. Higher order approximations to eqn (5) should also consider semiannual structure in oceanic conditions since seasonal stratification results in a more rapid rise of SST as the seasonal thermocline develops. 